Article

\title{
From Talking Heads to Communicating Bodies: Cybersemiotics and Total Communication
}

\section{Ole Nedergaard Thomsen}

Department of International Culture and Communication Studies, CBS—Copenhagen Business School, LaCoMe — Center for Language, Cognition, and Mentality, 15 Dalgas Have, DK-2000 Frederiksberg, Denmark; E-Mail: on.ikk@cbs.dk

Received: 31 December 2009; in revised form: 1 February 2010 / Accepted: 1 March 2010 / Published: 5 March 2010

\begin{abstract}
Current linguistics is biased towards considering as object of scientific study only verbal language, i.e., ordinary language whose basic entities are words, sentences, and texts. By having this focus, the crucial non-verbal semiotic contributions from acts of bodily communication are left out of consideration. On the face of it, this is a strange situation, because, phenomenologically, when observing a communicating dyad, what appears to the senses is a multimodal semiotic display-the interactants produce acts of total communication, the linguistic part of which has in fact to be disentangled from the integral semiotic behavior. That a human being should in the first place be conceptualized as a 'talking head', rather than a 'communicating body', stems from at least four historically interrelated fountains: ancient Greek philosophy with its emphasis on logos as meaning both rational mind and verbal language/speech as well as with its rejection of rhetoric (including body language); Cartesian dualistic rationalism where the body was the animal, mechanistic part of a human being, unworthy for the Geisteswissenschaften; Saussure's formal structuralism with its defocusing of the individual's performance, parole, and its high focus on societal langue; and Chomskyan linguistics with its neglect of actual, also bodily, performance, and its total focus on an ideal mental grammatical computational competence. With the recent philosophy ('in the flesh') of the 'embodied mind', time has now come for integrating the (linguistic) head with the (other part of the communicating) body and seeing communication as total communication of the whole body. This means that the communicating mind is no longer restricted to its 'rational' aspects but has to be conceived full-scale as integrating also all kinds of 'irrational' factors, like emotions and motivations. Another, no less important, implication of the above is that an individual's 'language faculty' is to be understood rather as a faculty of total communication-verbal
\end{abstract}


and non-verbal semiotic behavior is an integrated, multi-modal whole of total communication performed by whole human organisms. Cybersemiotics offers itself here as the meta-theoretical, transdisciplinary framework within which this new paradigm of total communication can be developed.

Keywords: Cybersemiotics; Peircean (bio-) semiotics; autopoiesis; cybernetics; functional linguistics; biolinguistics; pragmatics; InterPragmatics; verbal communication; bodily communication; gesture; total communication; communicative competence

\section{Introduction: An Ultra-Short Outline of Cybersemiotics}

Cybersemiotics [1], as the name indicates, is a transdisciplinary framework [2] which represents the coherent integration of, on the one hand, second order cybernetics and autopoiesis theory [3,4], and, on the other, Peircean biosemiotics and human ethology [5]. The model is an evolutionary process theory and as such integrates the objective informational [6] and the meaningful semiotic [7] aspects of cognition and communication. The point of departure of Cybersemiotics is, minimally, an intersubjective, dialoguing dyad of concrete individual human beings with a social-communicative, embodied semiotic mind-with a common language faculty and a consciousness-they are 'the observers put into the observed' of second-order cybernetics. From this basis we obtain knowledge in four irreducible dimensions of reality: the physico-chemical natural world (energy, information, and matter), the biological world of embodied experience (life), the psychological world of conscious experiential mental life (consciousness), and the socio-cultural world's intersubjective actions and communications (language and meaning). Thus, although we live in one universe, we also in some sense live simultaneously in four different 'worlds'. This may be represented as in the cybersemiotic star $[1,2,8]$ shown in Figure 1 [8].

Central in the model is the intersubjective, communicative semiotic activity performed by at least two human organisms (bodies with their embodied minds), termed linguistic cyborgs, i.e., animals preprogrammed for language and speech. That it is a communicative dyad and not a thinking 'monad', like The Thinker by Rodin, is important, for an individual human being and his or her language cannot be understood except in the context of a fellow human being and a human society and culture, to which they belong. Their language is public, intersubjective, manifested in semiotic communicative interaction-they do not speak a private, subjective language each, this would be impossible, as in the short story Ein Tisch ist ein Tisch by Peter Bichsel. Not even their minds are totally private: all sorts of empathizing occur, and emotions may surely be directly read off from their indexical facial expressions (cf. the proverb, "the eyes are the mirror of the soul”). Paradoxically, their faculties of language and mind are indeed personal belongings, 'inalienable', but then all the same they are collective, phylogenetically inherited-we are the symbolic species.

The communicative dyad engages in 'exosemiotic', inter-organism communicative processes on several levels, as shown in the communication model of Cybersemiotics [1,9], cf. Figure 2, representing the first stage of diagrammatization of Cybersemiotics [5,9]. 
Figure 1. The fourfold Cybersemiotic star [8].

"The semiotic star: A model of how the
communicative social system of the embodied
mind produces four main areas of knowledge,
which can also be analyzed to be prerequisites for
interpersonal observation and knowing. Physical
nature is usually explained as originating in
energy and matter, living systems as emerging
from the development of life processes (for
instance, the first cell). Social culture is explained
as founded on the development of meaning in
language and practical habits, and finally our
inner mental world is explained as deriving from
the development of our individual life world and
self-consciousness. All these types of knowledge
have their origin in our primary semiotic life
world of observing." [8]

Exosemiosis, or communicative semiosis, unfolds on three major, successive levels of communication, each including the other, in a hierarchy from top to bottom, thus representing total communication [4]. The top level (the uppermost horizontal oval) concerns intentional, rational, and purposeful 'socio-communicative autopoietic language games' (I will return to the concepts autopoiesis and language game below). It both represents the autopoietic social system (i.e., society) and the communicative processes occurring within it-following Luhmann, 'the social system is communicative processes'. (This may be the reason why the oval representing it is not in bold, which the other systems are, and that the lower-level communicative processes are represented by two opposed curved arrows.) It is further worth noting that social communication, in the form of language games, occurs at the interface ('interpenetration') between the psychological system and the social system. In the productive mode, the psychological system triggers speaking by way of communicative intentions. Beneath the language games system, there is a 'psychological system', iconically represented as the head, and a 'biological system', represented as the body-compare the upper part of the semiotic star above (life on the left and consciousness on the right in Figure 1). Notice that the two communicating linguistic cyborgs are surrounded by a circle. This symbolizes that normally the two people in the dyad belong to the same socio-communicative sphere, or culture, from which they draw their mentality and world view, the combination of which can be called 'language-culture'.

The systems sharing of exosemiotic processes are 'autopoietic'. Autopoiesis (Greek for 'self-creation') is a term stemming from the cybernetic cognitive biologist and neuro-phenomenologist Humberto Maturana [10]. It refers to the capacity of biological, living systems (e.g., living cells) to create and recreate themselves and to demarcate themselves from their surroundings on the basis of their own internal processes; systems strive to individually uphold internal homeostasis. The organization of an autopoietic system is formally 'closed' on itself and is in this way self-referential and disjoint from other systems. Accordingly, information does not pass through from one system to another. Rather, two systems may be 'structurally coupled' or 'interpenetrate'-they are coordinated and co-adapt, whereby they become 'operationally coherent'. The concept of autopoiesis is generalized to also include society, or social systems, by the sociologist Niklas Luhmann [11]. The 
autopoietic aspect of the Cybersemiotic model is expressed diagramatically by the blue box to the left in Figure 2b (from [5]). Neither the psychological nor the biological system itself communicates, or is communication-there has to be interpenetration. That is, where the "head" interpenetrates with the "body”, we observe psychosomatic, instinctual, motivational 'sign games', which are communicative, as we see it in e.g., the mating games of higher animals (like flirting in humans, see Figure 12 below). On the lowest, unconscious, biological level, quasi-communicative signaling can happen between two corporeal trunks which are structurally coupled. This means that the structure of one system is dependent on the structure of the other system, but on a purely reflexive level, which does not involve the motivation necessary in instinctive sign games. This biological quasi-communication is termed 'cybernetic languaging through signals' and concerns reflex-like behavioral coordination, as seen in e.g., turn taking and yawn contagion, reflexive mutual smiling and gazing, i.e., unconscious signals that serve to synchronize group behavior. (These kinds of automatically released acts of behavior do not draw on the mirror neuron system, which is actively involved in consciously mimicking.)

Figure 2. (a) The exosemiotic aspect of Cybersemiotics [5]. (b) The autopoietic aspect of Cybersemiotics [5]. (c) The internal semiotics aspect of Cybersemiotics [5].

(a)

\section{EXOSEMIOTICS}

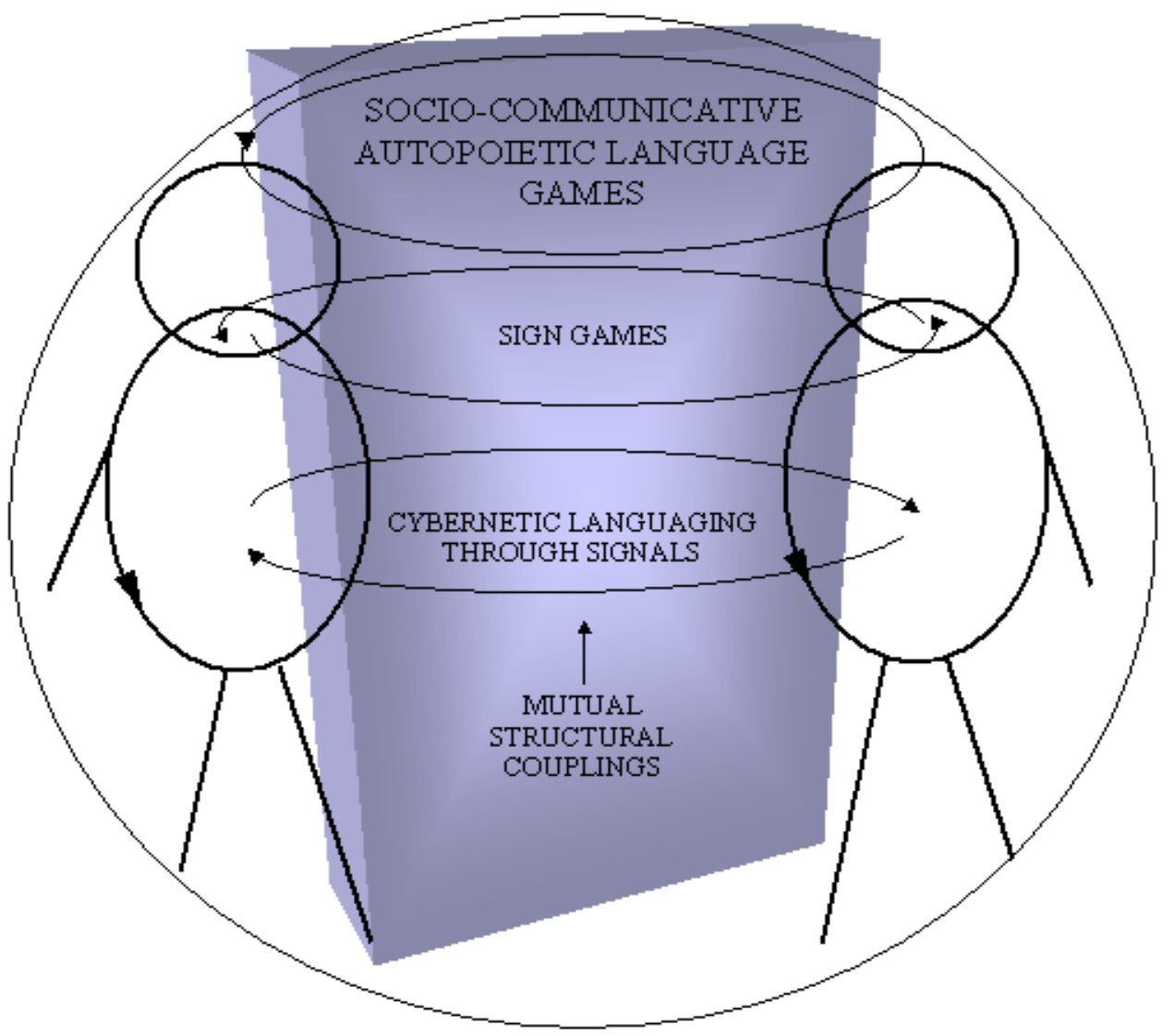


Figure 2. Cont.

(b)

AUTOPOIESIS

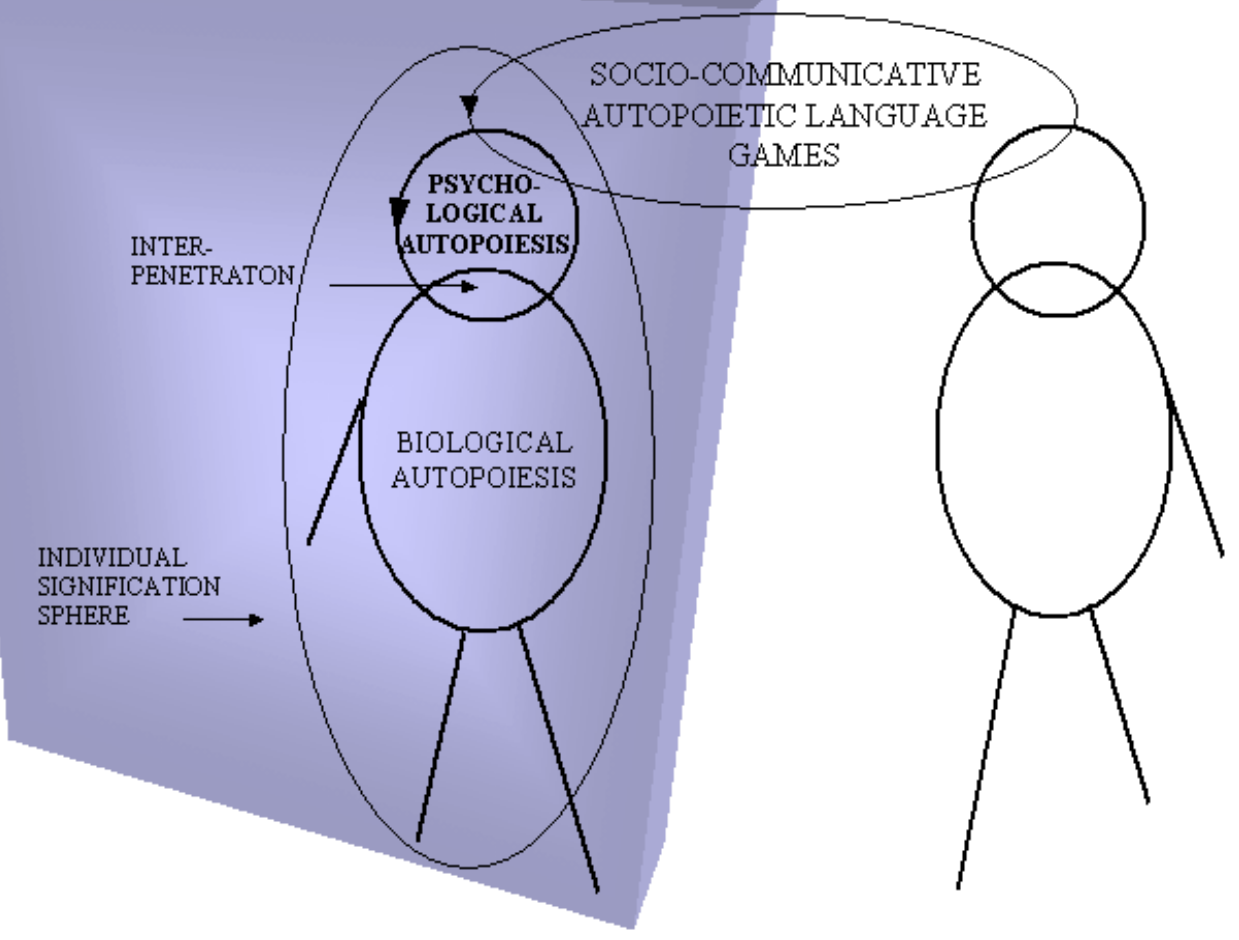

(c)

INTERNAL SEMIOSIS

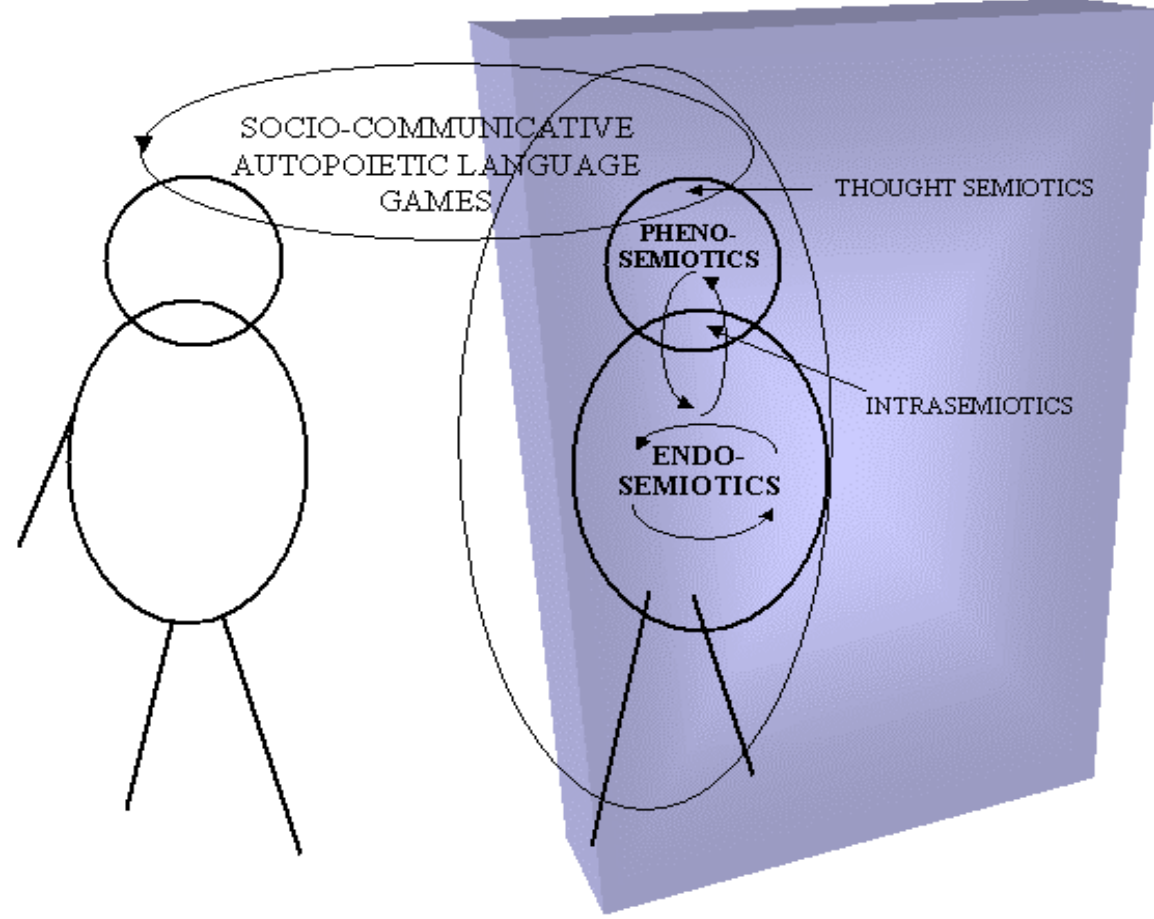


All kinds of communication require 'mutual structural couplings', or "contact", between two organisms connected via a medium of communication. With respect to language, this must imply that there is a structural coupling, within the 'social system', between two communicating linguistic cyborgs (or, 'natural language users' [12]). In the next section this will lead me to the claim that language as a semiotic resource is basically an individual's communicative competencephylogenetically inherited as a blueprint, but ontogenetically acquired, learned, and developed due to cultural-communicative input (a token dialect). Only on a secondary, emergent level is it a community language, a common norm (a type Dialect).

Also important in the model is the recognition that there are internal kinds of semiosis going on inside the individual linguistic cyborgs, as shown in the blue box to the right in Figure 2c (from [5]).

No conscious interpreter is required for internal semiosis to occur. Thus, we both find a level of unconscious endosemiotics in the biological autopoiesis system (corresponding to the exosemiotic languaging) and a level of conscious phenosemiotics within the psychological autopoietic system (experiences). Intrasemiosis occurs at the interpenetration between the body and the psyche. Thought semiotics is found at the interpenetration of the psyche and the socio-cultural system-implying that (discursive) thinking is verbal (oratio mentalis), or internalized speech and dialoguing. Notice the oval around the second cyborg: it indicates that a human being lives in a semiotic sphere of signification, on which more below.

As also alluded to above, Brier [4] states that the three levels of exosemiotics (the languaging, the sign game, and the language game levels) should be conceived of as successively included within and integrated with each other, so that the biological signaling level is included into the bio-psychological sign game level, and this in its turn is included into the socio-psychological language game level. This would imply, firstly, that the linguistic cyborg is an integrated communicative macro system, or a total communicator, and, secondly, that each level may develop into the next upper level, and that e.g., a subconscious-level phenomenon may be turned conscious and thus be monitored, or that a conscious- level phenomenon may become automatized and thereby a bodily reflex. This could be diagrammed as in Figure 3.

Figure 3. The communicative inclusion system of Cybersemiotics.

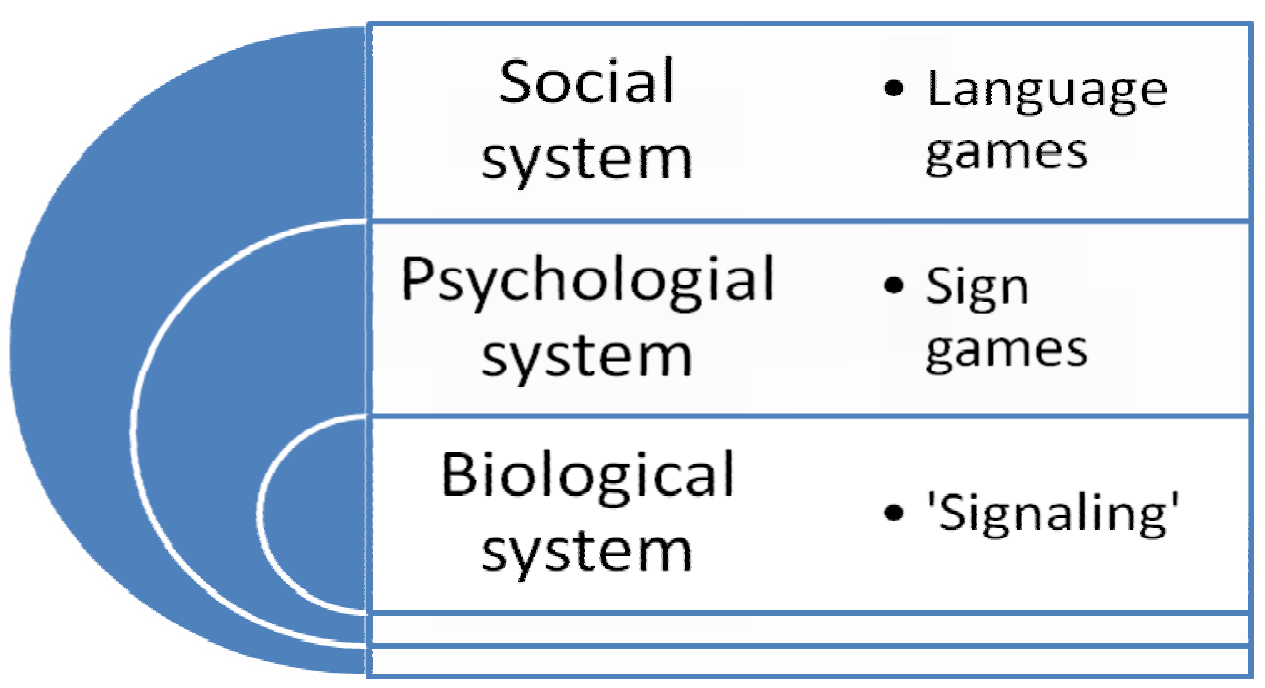


Logically, there are three autopoietic systems and two interpenetration (“interface”) systems. Internal to the interpenetration between the social system and the psychological system there is the kind of internal semiosis termed 'thought semiosis', mentioned above. That is, (conceptual) thinking ('reflection') is in the form of internalized language games. Some conceptual thinking occurs simultaneously with and is input to utterance formation, the so-called 'thinking-for-speaking' [13], or in general terms, thinking-in-communicating [14], recognized in psycholinguistics. In terms of Peircean semiotics, signaling is iconic-mimetic Firstness (coordination of coordination of behavior); sign games are indexical Secondness; whereas language games are symbolic Thirdness (conventions and habits). The tri-stratal model of total communication is explainable by its semiotics-there are no more semio-logical possibilities.

Brier [15] tries another diagrammatization which represents the all-inclusive character of the social system, as seen in Figure 4a where socio-communicative language games include the sign games, and cybernetic languaging through signals.

Here, the interpersonal social system is represented as a vertically placed oval that is inclusively based on the two lower levels of sign games and languaging, which precede the development of language games in evolution, and without which language games would be impossible as meaningful communication. This is an important aspect of what embodiment means in cognition and communication.

What is common to the representations in Figures 3 and $4 \mathrm{a}$, respectively, is the fact that human exosemiotics is an integrated system of total communication, seemingly dominated by the verbal language system (cf. "talking heads"). The difference between the two representations is that the one in Figure 4a is paying attention to the widely held opinion that a language is an inter- or transpersonal "capacity" of the whole speech community, whereas the one of Figure 3 stresses the fact that language is basically an 'internalized', personal competence of the individual linguistic cyborg [16,17]. I believe that the personal capacity conception is basic (a token), corresponding to a mental organ and a cultural instrument (cf. Chomsky's i-language; Coseeriu's functional language), whereas the interpersonal “capacity” (cf. Chomsky’s e-language; Saussure’s langue; Coseriu's historical language; social norms) is derived (a type). In the standard Cybersemiotics model, human language is not a biological or socio-psychological faculty, only an extra-personal, sociological process. I find this conception incompatible with an evolutionary conception of human language, as biologically evolved and co-evolved with the human mind/brain. In fact, Brier in [18] suggests that the interpenetration between an individual's (silent) psychic system of consciousness and the collective's social system of communications may be so strong that a system of its own has evolved: a self-conscious linguistic subject. Herein, then, collective, or we-, intentionality [19] would naturally reside.

The full-blown model of Cybersemiotics captures the fact that human communication occurs within an environmental context. This is the purview of so-called 'ecosemiotics' (where eco refers to the cultural ecological niche of the individuals and collectives) [20], as represented in Figure 4b [15].

The (primarily natural) environment is represented by the blue vertical bars to the right and the left of the drawing-the 'ground' so to speak, on the basis of which the communication 'figure' (the red oval in the middle) is discerned. Verbal communication then is the occurrence of socio-communicative autopoietic language games on this background. However, (cultural) communication does not occur on its own, it requires a cultural signification sphere (the bright blue, all-encompassing circle in the 
middle). The cultural signification sphere is so-to-speak the "buffer zone" between cultural communication and the (natural) environment. More precisely, communication is performed by individual linguistic cyborgs. However, they do not perform in isolation: each communicator is surrounded by his or her own individual signification sphere (the blue vertical oval around each person).

The significations within the signification sphere is the result of the individual's interactions with his environment-on the lowest, biological level they are primitive structural couplings, on the bio-psychological level they are instinctual-motivational, and on the psychological level they are conceptual, whereas on the highest, psycho-social level they are linguistic-semantic (not represented in the figure; i.e., the significational, ecosemiotic counterpart of the internal semiotic thought). One may say that not only is an autopoietic system differentiated from its environment, it is also structurally coupled with it. Following Maturana, this structural coupling gives rise to knowledge (including know-how) and cognition, within the system, about the environment [10,21-24]. The environment is represented in the system as signification-the environment 'means' something to the system. In so far as there is both the integrated macro system of the individual linguistic cyborg and of the supraindividual culture, there is both an individual linguistic cyborg's knowledge and the collective cultural knowledge of the speech community.

Figure 4. (a) Socio-communicative autopoietic language games as all-inclusive [15]. (b) Cybersemiotics, the full-blown model, including ecosemiotics [15].

(a)

EXOSEMIOTICS

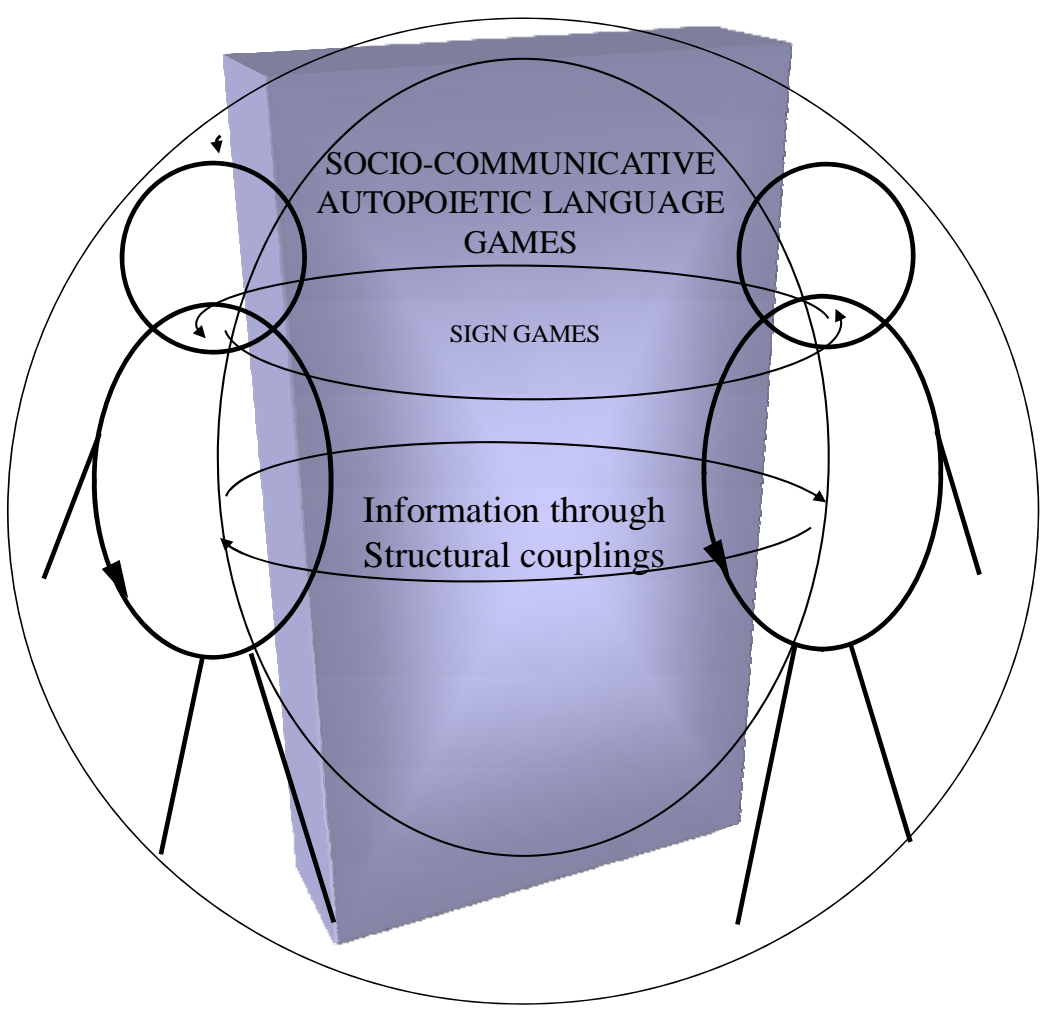


Figure 4. Cont.

(b)

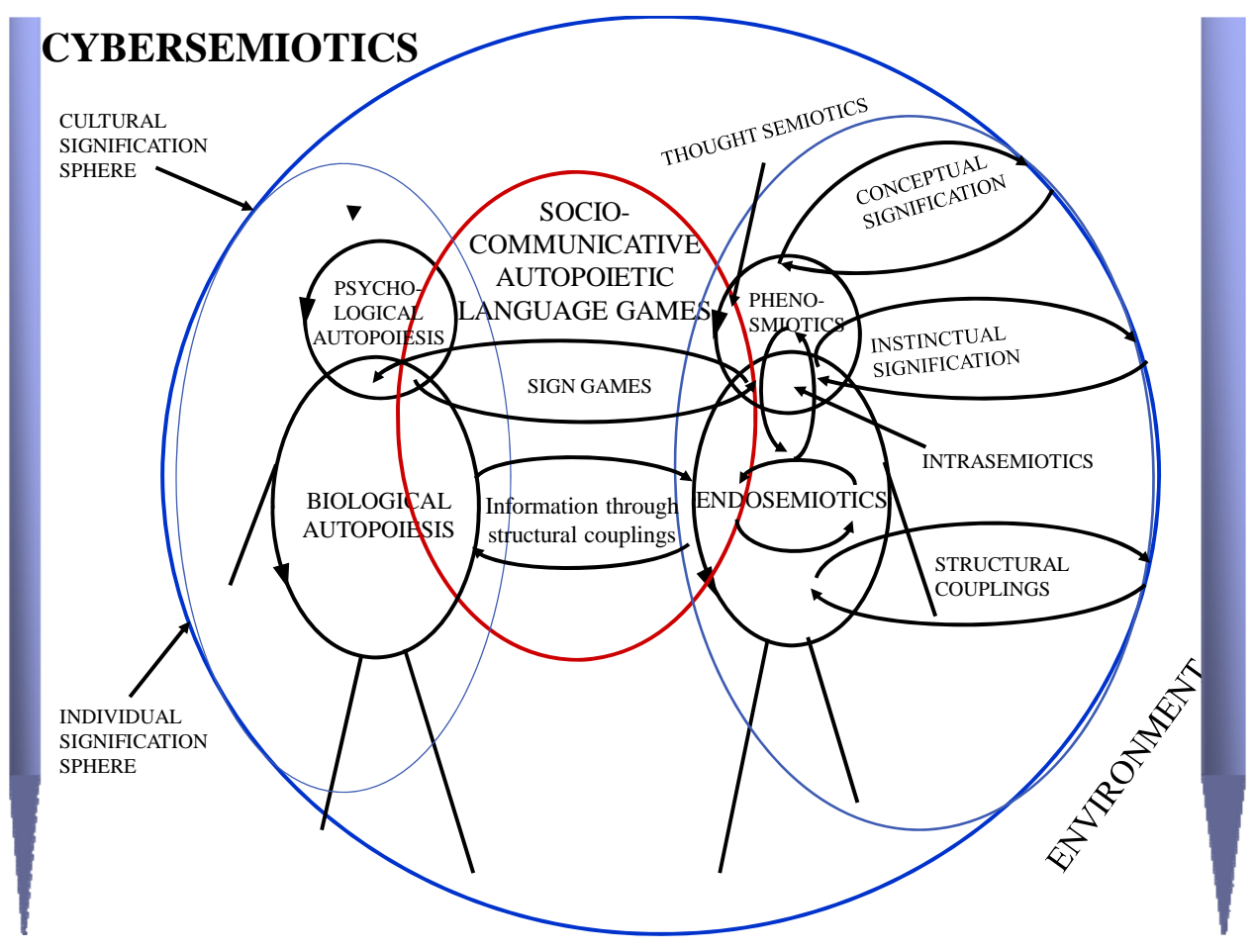

The environment is a substratum of 'triggers'. It is the dynamical object of semiosis, and is represented in the system by representamina and interpretants (meanings). The biological system has sensory-motor structural couplings and quasi-cognition-the signification of the environment is proto-semiotic. The psycho-biological interpenetration yields motivational instinctual signification, and the psychological system yields conceptual signification (phenomenal space). Additionally, the psycho-socio-communicative interpenetration gives rise to linguistic signification, or linguistic meaning, at the highest, social level, however absent from the diagram above, as just mentioned. Linguistic meaning is one of the crucial, irreducible factors recognized in Cybersemiotics, as is evident from the diagram in Figure 1, where 'meaning' is shown as belonging with society and language, however applied by embodied conscious language cyborgs. The difference between linguistic signification and conceptual signification hinges upon the viability of non- or pre-linguistic concepts: do we have concepts in our consciousness that are not matched with linguistic signification? I think so: for instance, prior to linguistic naming of a concept, e.g., deriving from perception, there would have to be a prelinguistic concept (i.a. discovering a new species in biological nature or a new kind of particle in the physical world). Conceptual signification would seem to correspond to the meaning 'substance' of Cognitive Linguistics, to be 'formed' as the specific conventional linguistic signification. According to the non-solipsistic Cybersemiotics, the environment is real. We have an imprint of it ('signification') which is structurally determined by our autopoietic make-up (e.g., our perception system), developed through an evolutionary interaction with the environment. Thus, there is a derivative "environment" which is our construction: each species lives in its own 'signification sphere' (multiverse) triggered by the environment (substratum in Maturana’s terminology, a plenum). 
A linguistic cyborg lives in an individual, organismic signification sphere; the communicative dyad/the socio-communicative system (culture) functions in relation to a collective, cultural signification sphere. The exact relation between these two spheres of signification is not defined in Cybersemiotics, but in my individualistic version, the cultural signification sphere would have to be the union set, or aggregate, of the individual signification spheres within a given culture.

I shall propose that we abandon Luhmann's depersonalized conception of the psyches as the surroundings of communication, and instead claim that all persons (linguistic cyborgs) are the surroundings of all other persons. This means that each person builds a "picture" of a given other, including his language, as part of his own individual cognitive domain (signification sphere)-the other person (concretely or generalized) is inside the individual's signification sphere. This way common knowledge (and know-how), including language, is being built up, by way of generalization. Each person also interacts continuously with himself, e.g., sees himself (i.a. when gesticulating), hears himself (i.a. when speaking), and perceives others' reactions to him (i.a. when communicating). Therefore, he also constructs a picture of himself inside his own signification sphere. (Compare Luhmann's distinction between alter and ego $[11,18]$.)

The environment in Figure 4 is mainly restricted to the natural, physical world of Figure 1, surrounding the individual and the society. Physics is of course also an essential part of the communicative system, which is depicted in Figures 2 and 3. In the case of communication, physical matter is naturally the carrier of the linguistic signs encoded in speech.

\section{Linguistic Communication in Cybersemiotics}

Cybersemiotics, for its general conception of communication, is based on Luhmann's concept of society as a social system based on communication $[3,4,11,18]$. Insofar as Luhmann did not develop a true linguistic theory as such, Brier qualifies the linguistic aspect of Luhmann's concept of linguistic communication by Wittgenstein's pragmatic-linguistic concept of 'playing language games'. Language games, in Cybersemiotics, are 'autopoietic', in the sense that society can recreate itself via its members and their communications. The concept of 'society' in Brier's interpretation would be what in linguistics is called 'speech community'. In Luhmann's theory, the bio-psychological individual human being is left as solely a surrounding (or, instrument) of this communicating society. It is comparable to a kind of marionette "puppet” that does not communicate, only thinks (prelinguistically) and interacts bodily. Cybersemiotics questions this state of affairs and points out a missing link between society (communication) and its human bio-psychological surroundings (linguistic cyborgs), a link that inserts the crucial concept of embodied persons who actually perform the communication, i.e., actively 'select' meaning, encode it, utter the corresponding linguistic expression, perceive it, decode it, understand the original meaning, and react accordingly [4,18]. Thus, Cybersemiotics admits of concepts from speech act theory and conversation analysis and accordingly becomes compatible with speaker-oriented functionalist linguistics [12,17,25], which requires that linguistics be not only pragmatically but also psychologically adequate.

From an outsider's point of view, the surroundings of Luhmann's 'society', i.e., the linguistic cyborgs, ad up to a union set, reified as a Saussurean masse parlante, so that communication is in fact reflexive, intra-semiotic on a macro level: roughly, society is speaking with itself! This 
supra-individual conception of communication should be abandoned as reification in Cybersemiotics for this theory to be compatible with basic insights of psycholinguistics (speech production and reception; language acquisition) as well as of linguistic pragmatics and speech act theory. It is indeed human beings (natural language users, linguistic cyborgs) that communicate, not society-society is rather created by the individuals and their use of language in communication [26], as mentioned above; society is a 'perlocutionary' effect so to speak [17,27]. But-of course-individuals are then again formed by the linguistic culture in which they grow up. More precisely, social institutions are created and developed by human agents and their communicative interactions, and their language itself is also one of those social institutions (albeit in the form of individuals' communicative competences)perhaps the most basic one, the one on which the others depend [26]. This is still an example of autopoiesis: self-creation, but one from bottom-up, not from top-down: language is reproduced by being used, for instance when it is acquired by children in 'learning-by-doing'-they form it individually [25], but a top-down effect could be said to exist in so far as the surroundings from which they learn their language is a subset of the union set mentioned above, the speech community, and its communications.

If we for now leave the 'collectivist', Luhmann approach to social systems and instead build on a Searlean, methodologically individualist foundation, the social system as a linguistic communicative system (cf. langue) should henceforth be primarily understood as an individual's capacity to communicate, i.e., to use the cultural-linguistic system that he has 'reconstructed' from the surrounding society, i.e., the speech community in terms of its individual speakers $[16,26,28]$. The language user is born as a pre-linguistic human animal, but with a capacity for language [29]. The language of his surroundings turns him into a linguistic, conscious human being. In the same vein, the two surroundings of communication in Cybersemiotics-the biological and psychological systemscould be seen as capacities beneath the linguistic communicative system, capacities to 'signal' and to play sign games. Taken together, and successively included into each other, these three capacities constitute the human communicator as a social agent. A human communicator, then, in the model proposed here, is accordingly a macro system-an autopoietic semiotic-cybernetic organism, a semio-cyborg. And it is the claim of the present contribution that a human being is far more than a homo loquens-it is a homo communicans, a person (capable of and habitually) engaging and engaged in total communication [30].

Within verbal language, speaking and understanding speech (together, dialoguing) are cybernetic processes governed by servomechanisms (the feedback function). In Peircean terms, speech reception and language acquisition and learning are abductive processes [25,28], thereby meaning that, with respect to speech reception, the input is the acoustic expression and the output the message content (the speaker's utterance meaning as hypothesized by the hearer); with respect to language acquisition and learning, the input is also the acoustic signal, whereas the output is the functional language of the speaker, as hypothesized by the hearer-learner. In one sense, it is only the perceptible material-objective communicative signals that are public and palpable, “out in the open”, communication being peripherally-instrumentally signal transmission (i.e., production \& perception), not message-content packaging and un-packaging. A language in the concrete, primary sense of a rule system for playing language games is a personal achievement, operative in the individual-even though it is a 'public language' (collective norms “in force”), abduced from the speech of the linguistic 
surroundings of the concrete language user. The Popperian third-world-ness of language is due to my presuming that we-I and you-are using the 'same' (or similar) norms. Language acquisition is cybernetic testing and learning-by-doing: on the premises of phylogenetic language universals and the surrounding linguistic usage, the acquirer proposes as a hypothesis his version of the norms in force and deduces usage himself (testing); feedback reactions-in the form of judgments of congruence, correctness, and acceptability on the part of the linguistic-communicative surroundings-are input to his continually revising his communicative devices [17].

Now, we are in a position to flesh out a Cybersemiotic model of linguistic communication, alias the cultural practice of playing language games. In order to do so, we shall begin with two crucial linguistic models of a dialogue: first, the model of the 'speech circuit' by the founding father of modern linguistics, Ferdinand de Saussure [31], shown in Figure 5 (a); and second, the psychologist and psycholinguist Karl Bühler's so-called organon model [32], a model that conceives of communicative utterances, or discourses, as instruments (Greek organon) of human interaction, and derivatively language as an instrument of communication [12] (and cognition), repeated here as Figure 5 (b). De Saussure's model of speech as a dialogic circuit is important because it stresses the mental phases of communication: the retrieved conceptual structure triggers acoustic images in the mind of the speaker which are then transmitted to the hearer via phonation; the hearer in her turn converts the acoustic signal into an acoustic image in her mind (audition) before having this trigger the corresponding conceptual structure in understanding the speaker's speech act (parole) (notice de Saussure's picture of “talking heads” rather than “communicating bodies”). Bühler's model is not a symmetrical, dialogic model, but an asymmetrical, monologic one; see Figure 5 (b).

Figure 5. (a) Talking heads: de Saussure's model of the speech circuit [31]. (b) Bühler’s organon model [32].

(a)

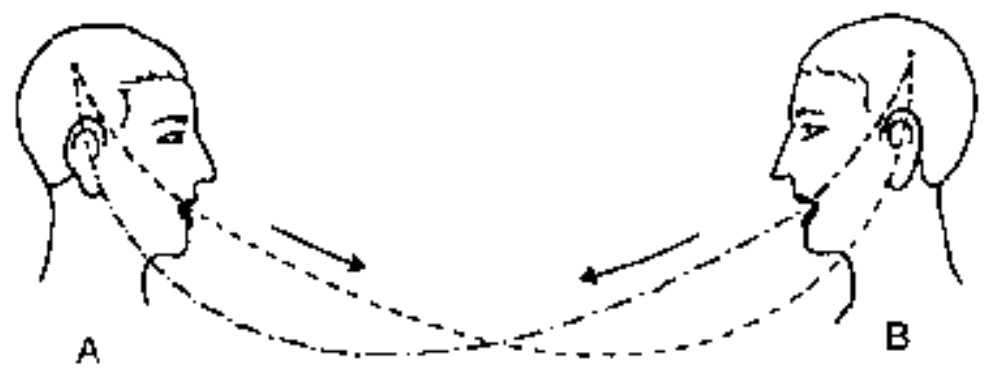

Aucition

Fhon:aicon

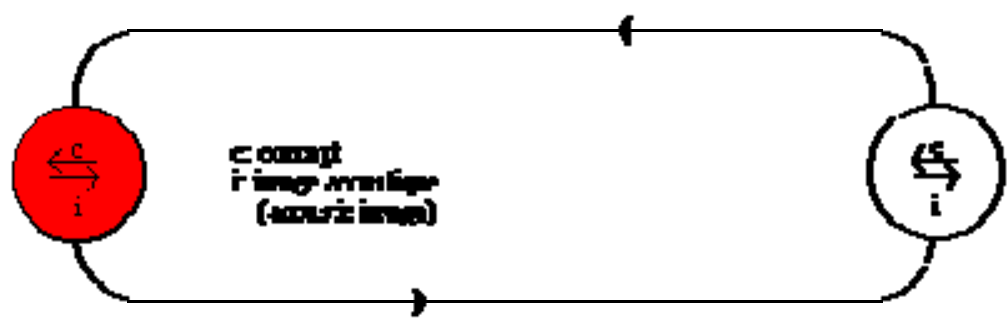


Figure 5. Cont.

(b)

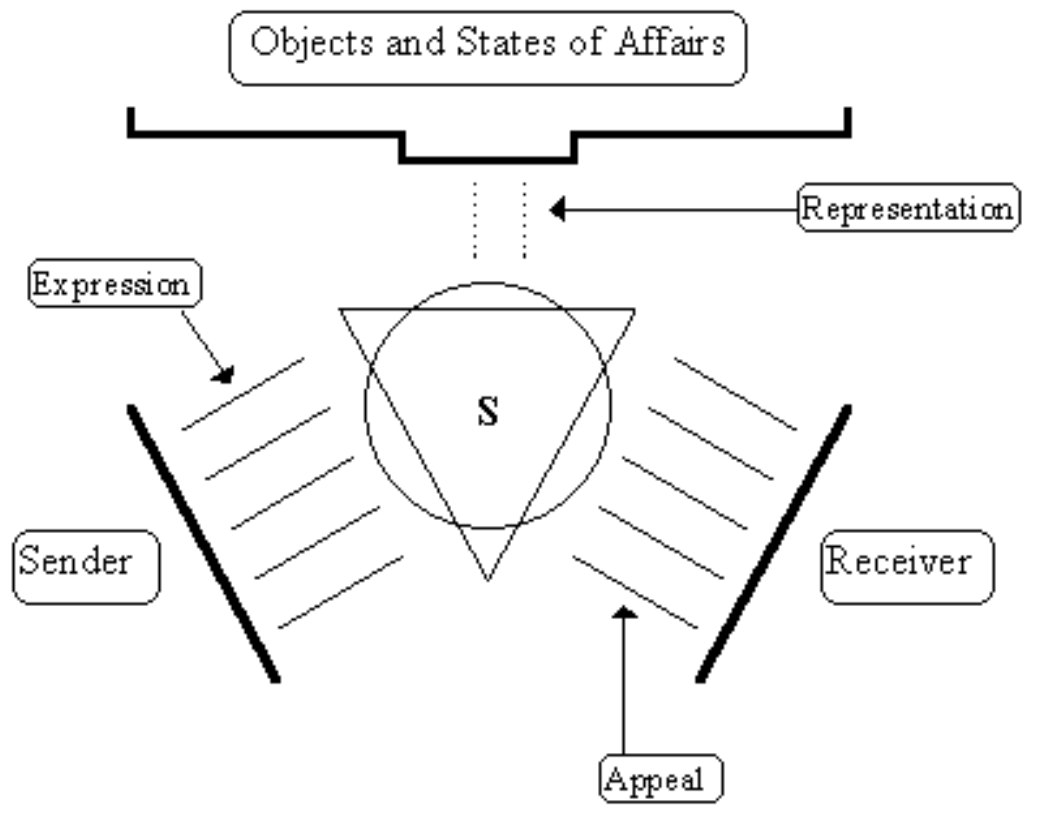

In explaining Bühler's model, we shall also use some terms and concepts gleaned from Peircean semiotics and speech act theory. The diagram in Figure 5 (b) is to be read as follows: a sender (first person, or speaker) produces an acoustic signal (the circle in the middle of the model) which the receiver (second person, or hearer) perceives-the speaker performs a phonetic production act ('phonation'), the receiver an act of speech perception ('audition'), in speech act terminology. The signal is a 'perceptible'; it is indexical with respect to the sender's physiognomy (e.g., age and gender) [33]. By being produced and intended as a sign (capital $S$ in the figure) by the sender and by being addressed to the receiver as being about some objects and states of affairs, this perceptible is a sign vehicle (i.e., implement, or 'organon' of representation, i.e., Peirce's 'representamen')-it functions, or counts, as a sign (the triangle in the diagram). The objects and states of affairs, which the sign is 'about' ("third person” spoken of), are the '(dynamical) object' (primarily belonging within the environment in Cybersemiotics). By uttering the sign, the speaker performs referential and propositional acts concerning this referential matter, and the hearer performs corresponding reception acts. The sender and receiver are 'interpreters' (cognizers) in whose psyches (i.e., the socio-psychological interpenetrations) 'interpretants' (messages) form, which mediate between the two other factors of triadic semiosis, the object and the representamen. Notice that the concept of interpretant is absent in Bühler's model. The interpretants are accessed from the individual's signification sphere (see Figure $4 \mathrm{~b}$ above).

The representamen is in the first place an acoustic qualisign (the circle above), which is an objective occurrence. In relation to speech production, it is a Peircean 'singular' sign (a sinsign) related to the sender, whereas in perception it is a sinsign related to the receiver. In these capacities as signs it is represented as the triangle with the capital $\mathrm{S}$ in the middle in the diagram. Both sinsigns are tokens of types, by Peirce called legisigns. The legisigns are a function of an expressional 'code', in linguistics termed phonology [25], which is absent from Bühler’s triangular model, but would have 
turned it into a rectangle (horizontally: sender-receiver; vertically, top-bottom: context-code). The sinsigns are instantiations or manifestations (realizations, materializations) of the legisigns. Ordinary discourse is connected, so that the sinsign is a multiple manifestation of several, sequentially ordered legisigns (cf. Saussure's principle of linearity) representing the syntactic structure of the language. In a wider concept of 'code', the legisigns are the expression sides of linguistic symbols, i.e., the conventional correlation between a given legisign and its denotational object. However, in a concrete utterance situation, the representamen is an index-the sender 'points to' (and attracts the receiver's attention to) the referential objects and states of affairs denoted by his utterance [27,34].

The implementational side of communication should not be left out-as in Brier's general overviews above, and in Boye's attempt at developing a Luhmann inspired linguistic pragmatics [35]-because communication is outwardly a matter of human physiology (sensory-motor systems), i.e., the biological system of Cybersemiotics. That is, it is not adequate just to say that the psychological system makes meaning selections which are then input to society (the socio-communicative language games). Rather the human communicator communicates with his whole body, i.e., articulates and perceives. The ultimate outward reality is naturally the physics of speech.

Another facet which we have introduced into Cybersemiotic linguistics is the pragmatic phenomenon of reference. Lastly we have touched upon the linguistic code, both the phonology and the symbolizational code (i.e., the double articulation of language). However, there are still a couple of constitutive factors of a Cybersemiotic model of verbal-linguistic communication that have to be introduced. The first of these is closely connected to the uttered signal: this is the physical 'channel', which we inherit from Roman Jakobson [36]. The channel is important in that it is the material path, e.g., sound, through which the signal 'travels'-to speak metaphorically. Roman Jakobson's classical communication model [36] is given in Figure 6, where the factors of communication and the corresponding (speech) functions are shown together.

Figure 6. Jakobson’s communication model [36].

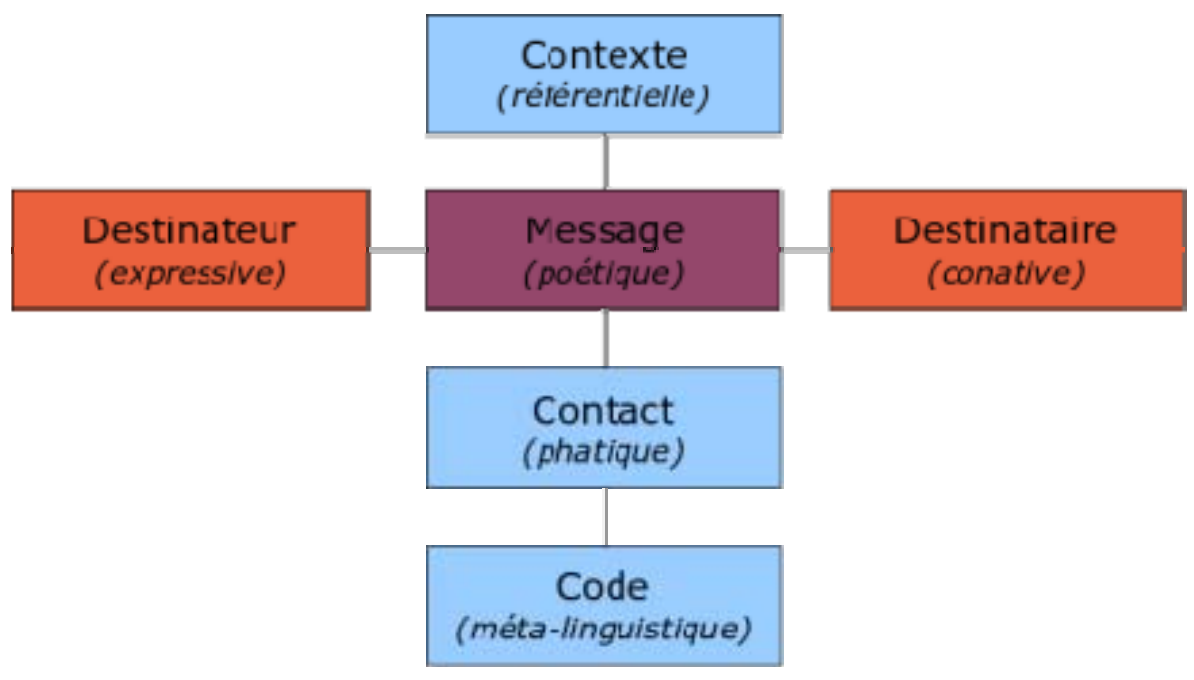

For a sender and a receiver to be 'structurally coupled' and thereby to be able to communicate with each other, they have to be mutually accessible. They have, on the bio-physical side, to be able to articulate and to perceive one another's utterances, and on the psychological side they have to be 
psychologically connected, even though in principle they are black boxes to one another. In sum, there has to be established a 'contact' ("physical channel and psychological connection” [36]) between them. Each communicative situation is basically a verbal encounter [37], and the focus on this in the message yields 'phatic communion' (the communication of social ties through speech). In Cybersemiotics this would be the most basic speech function, concerning as it does the socio-cultural nexus between two persons, their verbal intercourse. The code represents a semiotic contract, the other kind of coordination (and "approximation") between two linguistic cyborgs. A focus in the message on the code yields Jakobson's 'metalingual' function. In Jakobson's model, the sign concept (the physical signal) in Figure 5b is replaced by the concept of the 'message', primarily the discourse negotiated between the sender and the receiver. This message is automatically correlated with its "universe of discourse”, termed 'context' ('objects and states of affairs' in Figure 5b, i.e., the environment in Cybersemiotics, Figure 4b). Focus in the message on this factor yields the 'referential' function. In Jakobson's conception, the message is actually both expressional (representamen, cf. the channel part of the contact) and contentive (interpretant, cf. the psychological connection part). When the message is focused on in itself, as an object of communication, as a creational object (i.e., Aristotelian ergon [16]), rather than as a process (energeia) or as the language structure behind (dynamis, i.e., the linguistic-communicative competence, the code), we have the important 'poetic' function concerning the rhetorical-stylistic-aesthetic make-up of the discourse, e.g., as a work of verbal art.

The most important of the constitutive factors of Jakobson's original model, according to many linguists [38], is the factor of the 'code', which is the (functional discourse) grammar (including lexicon) of the given language. It is what characterizes the specific language as a convention or 'contract' agreed upon by the users of the given language. Each signal produced is a manifestation of a coded message (the latter being an application of the code on the message input). Linguistic contents are encoded and decoded via the symbolization norms of the language. However-what is not normally considered [17]-each communicative event simultaneously involves, in addition to the object level of normal communicative conduct, also a meta-level focusing on the language used (cf. Jakobson's 'metalingual' function above). This level comes in two sublevels, viz. a 'legislative' plus an 'adjudicative' sublevel [17]. The former concerns the fact that language is negotiated by the communicators, sometimes explicitly (as when new terms are introduced, new pronunciations proposed), sometimes tacitly (the very use of the code is a signal to the hearer that this is the code he has to follow-this is the 'promulgation' or "publication” of the code). The latter sublevel is operative when the communicator judges, sanctions, and corrects the usage of his communication partner (and of himself in self-correction). The norms of the code function as criteria in the adjudications. Any communicative activity is then judged for its conformity with, or deviance from, the accepted norms: the message may be incongruent (e.g., illogical) or unacceptable (e.g., inappropriate in the situation), the expression may be wrongly pronounced, and the grammatical structure may be incorrect. In addition, there is a bio-physical level where the utterance may be, e.g., ill formed as due to a speech deficit. The adjudicative judgments are given on behalf of the speech community, to which the norms belong, they are impersonal. The communicators as language legislators may deliberately construct a politically correct language (the Language of the speech community), e.g., an orthography, according 
to which usage is then adjudicated. This Language has to be internalized to be operative, just as the laws of a given society must be known by the single citizens in order to be followed.

In the preceding, we have more or less been concerned with the semiotic aspects of linguistic communication. However, for a Cyber-semiotic theory of linguistic communication to be also cybernetically adequate, we have to go back to the original, well-known Shannon-Weaver, or 'active', model of the communication process [39], given in Figure 7a, and its more cybernetic revision as an 'interactive' model involving feedback and self correction, see Figure 7b. (We only focus on interpersonal communication here.)

Figure 7. (a) The Shannon-Weaver, active model of the communication process [39]. (b) The cybernetic, interactive model [39].

(a)

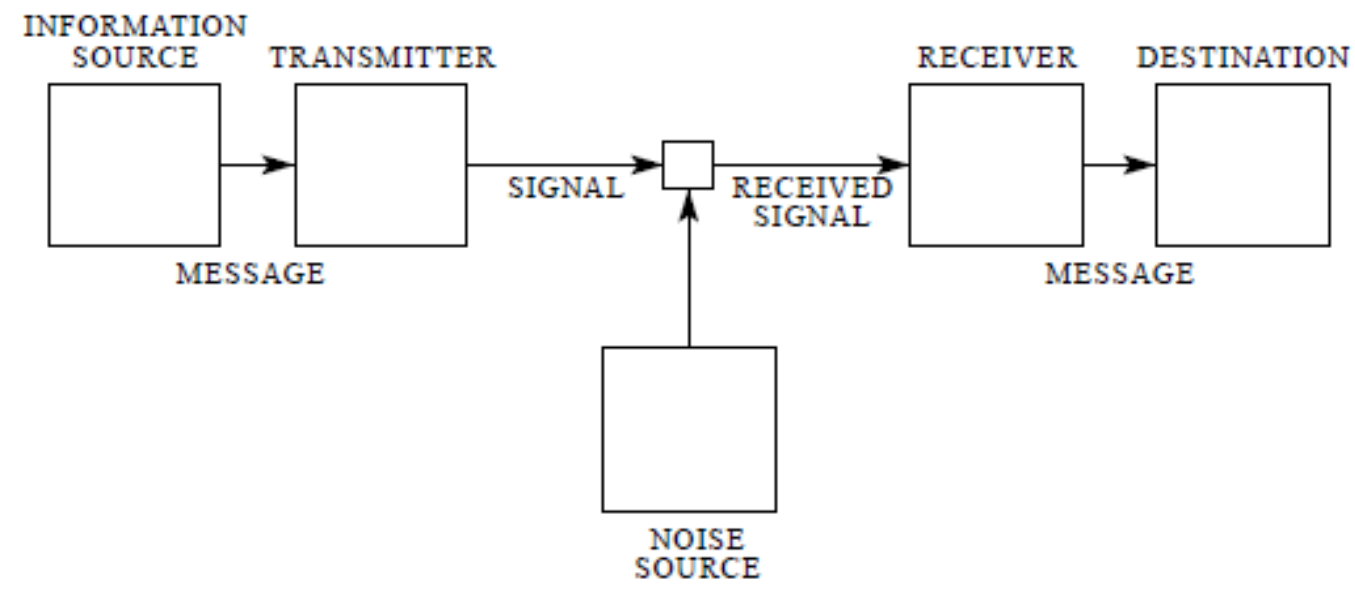

(b)

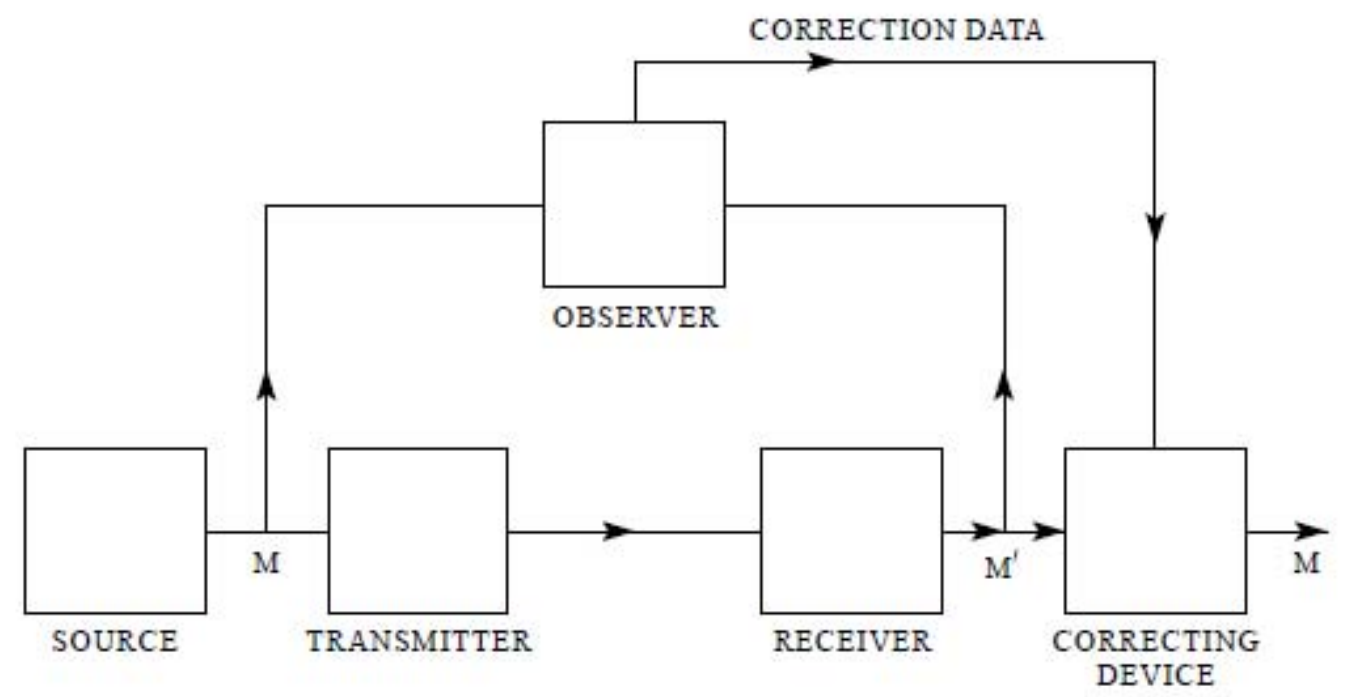

When compared to Jakobson's model we see the 'addresser' split up into two stages, viz. the 'information source' forming the message and the 'transmitter' articulating the signal; and the 'addressee' split up into the opposite stages of signal 'receiver' and the message 'destination' (the comprehender). Central in the model is the small box which represents the 'channel' (e.g., air or sound) conveying the qualisign, into which 'noise' may intrude from a 'noise source'. The 'signal' and 
the 'received signal' are the sinsigns introduced above. The 'transmitter' is the articulatory system, the 'receiver' the auditory system of interpersonal communication. Jakobson's 'message' is, correspondingly, both the (psychological) 'message' and the (physical) 'signal'. In terms of Cybersemiotics, the messages are the communicative intentions and the psycho-social processes forming in the psycho-social interpenetrations of the linguistic cyborgs.

Now, communication does really have an important cybernetic aspect in its process, involving feedback control of utterance production. It takes into consideration the possible outcome of a given communicative move (anticipated or after the fact), and adjusts production accordingly, either on-line, incrementally, or after the fact of the utterance production. Thus, we need the extra factor of 'feedback' to depict the proper functioning of the communication system, as shown in Figure 7b [39].

In this cybernetic model of communication, the communicator forms a message (M), verbalizes it and encodes it as a legisign that is transmitted as a sinsign and qualisign. The received signal is decoded and interpreted as a message. This message has some effects on the surroundings which are fed back into a control mechanism where the sender evaluates whether the effect was acceptable (e.g., his meaning was/was not understood), so that he can regulate his communicative behavior accordingly. In this sense, a communicator is a trivial 'machine'-'if you don't hear what I say, I'll speak louder; if you don't understand what I'm trying to tell you, I'll reformulate to obtain the desired result'. Each speaker is also simultaneously his own listener, so that feedback is additionally given from the channel in the middle. And, furthermore, each listener is also a virtual speaker, as is transparent from the motor theory of perception and a "creation theory of comprehension", where part of the comprehension activity is what you would do in the same situation as the speaker is in [29].

Before we can round off this section on linguistic communication in Cybersemiotics, we have to introduce the important concept and factor of the 'medium', which is a factor somehow including the factor of the 'contact' (channel) proposed by Jakobson. The medium is primarily the technology and institution used in communication, e.g., most basically the written vs. the spoken medium [40,41]. Much communication in the postmodern, information-communication and globalized societies is mass-medial and multi-medial. Medium is prominent in Foulger's [42] Ecological Model of Communication, cf. Figure 8.

This transdisciplinary model reconceptualizes the communicators as creators and consumers. This is in line with the fact that communication is a creative, 'poietic' process, where the language structure is not causally determining, only a "guiding principle". What is not present in the diagram is the prelinguistic meaning, i.e., the speaker's utterance meaning as well as the reconstructed meaning ensuing from the hearer's comprehension process, what is termed message in the previous diagram. The 'messages' in the present diagram are language-specific, formulated representations. An amendment I would like to undertake is that, corresponding to the distinction between the 'signal' and the 'received signal', there should be 'messages' and 'reconstructed messages', under the creator and the consumer, respectively, just as there should be creator's code (dialect, functional discourse grammar) as well as consumer's code, especially evident in cases of intercultural communication and code shifting, see Figure 8 (b). 
Figure 8. (a) The Ecological Model of Communication [42]. (b) A crucial amendment: language as a personal capacity.

(a)

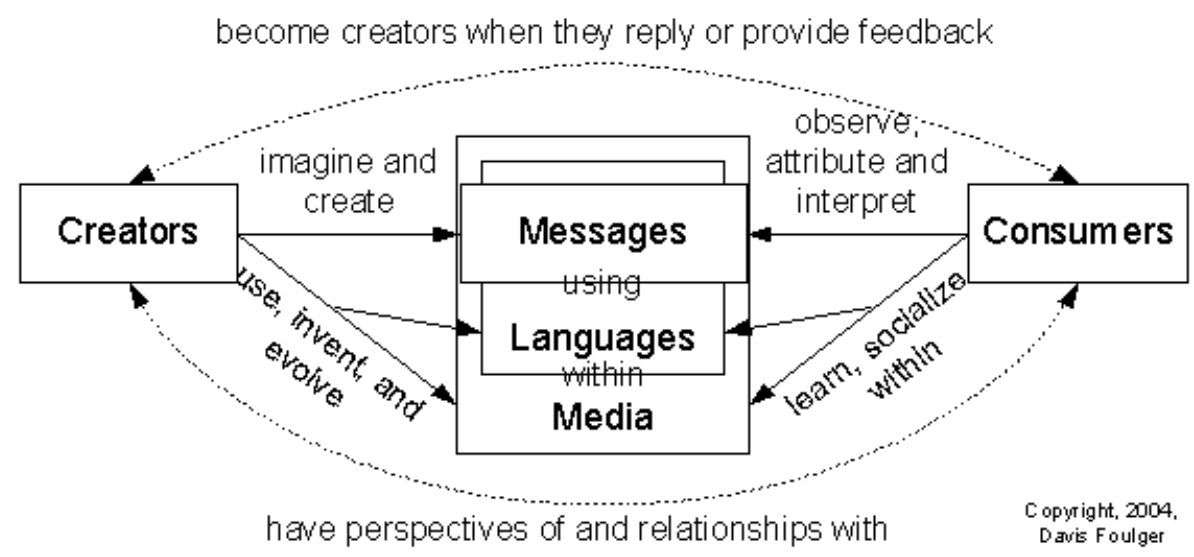

(b)

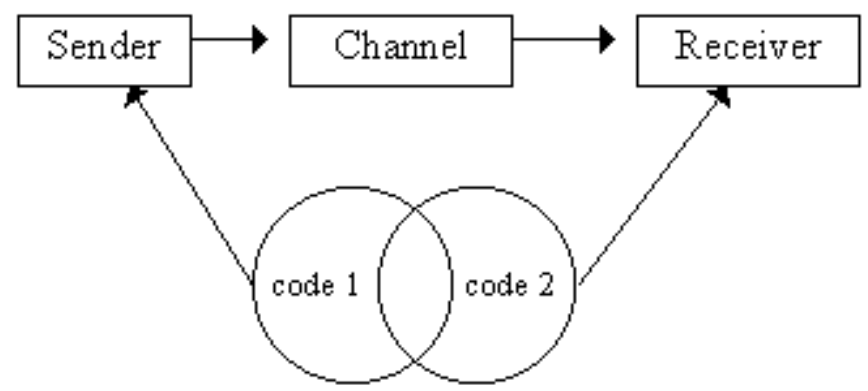

In the middle the channel should be retained, included in the 'media'. Notice also that the referential matter in the 'context' (Cybersemiotic environment) should be reinserted above the messages, as in Jakobson's model in Figure 6.

To round off this sketch of linguistic communication, I would like to make some Peircean-biosemiotic proposals that have some bearing on the matter at hand. First, communication should be grounded in perception.

In a cardinal perceptual situation (cf. the center of the Cybersemiotic star: 'knowing as semiotic activity') involving I-intentionality, as a background for communication, we have a perceiver (interpreter)-a psycho-biological system, an object of perception (Peircean dynamical object) in the environment, and the perceiver's sense impressions (sinsigns) of this object. Perception is then a kind of abduction (inference of a case, based on a result and a law): (1) sinsign-(3) interpretant (category of object $) \rightarrow(2)$ immediate object [1: Firstness; 2: Secondness; 3: Thirdness]. The immediate object is the hypothetical correspondent (2.1) of the dynamical object (2.2) of the objective environment. If we let this situation be mirrored by one consisting of another perceiver at the same time perceiving the same object, we have a situation of perception of the same real dynamical object in the environment, but now from a different perspective. Adjusting the picture a bit, now involving we-intentionality and mutual structural coupling, we have a situation of 'joint attention' to the same object, a triadic skill where each is aware of the other as the perceiver of the same object, compare Figure 9. (Joint attention 
may involve a sign game where one person directs the attention of the other by way of gazing or pointing.) This is a referential prerequisite for reference, proposition, and communication [43].

Figure 9. Joint attention.
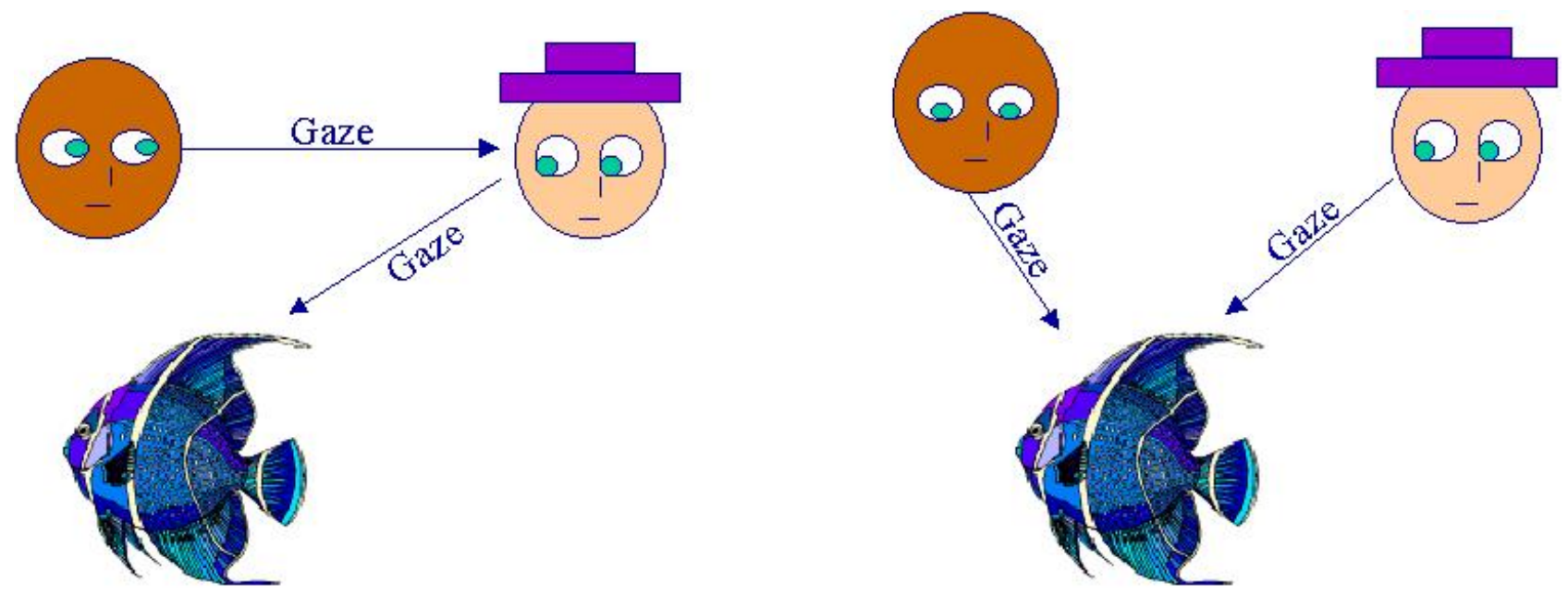

In a cardinal communicative situation, involving we-intentionality, let us assume that the same two persons are talking about the same object that they perceive. They need a shared 'code' each, in order to be able communicate about that same object, that is, each communicator necessitates his or her own linguistic capacity which should be functionally similar to that of the other communicator's; on which more below. Linguistic communication requires the concepts of communicative intentions (a kind of interpretants, 3): referential intentions (conceptual structures; 3.1) corresponding to the immediate object, propositional intentions (3.2), and dialogic-illocutionary intentions (3.3). These intentions are intentions of the sender occurring in the psycho-social interface system. In face-to-face communication with on-line talk about the same object, both this perceived object and the verbal qualisign connected with it would be co-present in the natural 'environment' as real entities (e.g., the object, fish, and the sound of the word 'fish'). If the communication situation is 'total', there might also be a pointing gesture co-present. The speech acts performed become social facts in the social-cultural environment, especially their perlocutionary effects.

Second, we need a conception of the communicative competence (including the symbolization code) as a deductive procedure, or know-how [33], a pattern of behavior, i.e., a set of deontic, directive rules, a communicative norm [45]: the competence is the major premise in a logical deduction, the coding task at hand being the minor premise; the solution to the task is the logical conclusion. So, if the communicator in the case above has a communicative intention (3.1) of talking about the perceived fish (2), he or she must choose the corresponding word content (linguistic interpretant, 3), and via symbolization, he has to word it (1) accordingly. The driving force behind embarking on the communicative deduction is the free will $[48,58]$ of the communicator to communicate-here the decision to talk about the fish.

\subsection{The Communicator as The Basic Social Level—Methodological Individualism}

I proposed in the introduction that society-an interpersonal autopoietic communication system-be understood instead as an individual's personal communicative capacity, the capacity for playing 
language games within a given language-with a technical term, his dialect. I shall venture that communicating man is (also) an autopoietic system, the atom of society. Society, in the sense of 'speech community', is the population of individuals sharing the 'same' (hypostatized) code (Dialect, with a capital D), meaning thereby that their individual dialects are compatible, that their communications succeed to a significant degree owing to this sharing (coordination, adaptation, and accommodation). This means that all individuals within the speech community are each others' potential communication partners. (The speech community is thus a 'paradigm' in the structuralist sense, a list of similar entities. Each communicating dyad or other participant constellation is accordingly a syntagm/nexus, an actual combination of entities from the list.) Seen from the Dialect's perspective (which is only metaphorical), the speech community is the ddomain of application or validity' of the Dialect. Likewise, the sign games and languaging are defined within a domain of application, the species or subpopulations thereof (without making the species autopoietic, which would be a biological parallel to Luhmann's social system). The signification sphere of the individual is the signification sphere also of his individual dialect, whereas the signification sphere of the speech community (the cultural signification sphere) is the union set of the signification spheres of all individuals forming this population, and the signification sphere of the Dialect. In this way inter-individual cultural variations are situated. Making the individual an 'atom' of society means making a distinction or drawing a line between him (his mind) and the other fellow members of the society (their minds) and the other surroundings.-All men are islands in this sense; they are black boxes, or unknowns, for each other. The social groupings and networks and the society (speech community) at large are the 'molecules' and more complex social structures.

If language were not the individual's personal communicative competence, there would be no explanation for the fact that usage and grammar are constrained by factors of processing, e.g., the avoidance of, or coping in an effective way with, complexity [44].

A crucial concept for understanding the human individual is her possessing of individual and collective intentionality, that is, her genetically inherited directedness towards the natural surroundings and her con-specifics, respectively [19]. As a communicating agent she is governed by a Gricean principle of cooperation, and she is responsible for her speech acts [45], as she is in general for all her (volitional) acts [46].

In order for Cybersemiotics to be pragmatically and psychologically adequate, methodological individualism should be subscribed to [47]: it is the communicators that communicate, on the basis of their intra-personal collective intentionality, their creativity, and their free will [48]. Thus, it is not and could not be 'communication' itself that communicates, as Luhmann has it, for "who", that is, what kind of (macro-) person, is 'communication' that "makes something common", and to "whom”?-It would then be to itself, i.e., a kind of reflexive communication. Luhmann's concept of communication is that of a non-agentive, transpersonal process. In the individualist model it is rather an agentive activity, a monologue (individual, I-intentionality), as a constitutive part of a dialogue, i.e., a reciprocal-agentive interaction (collective, we-intentionality). We collaborate in producing the discourse and dialogue. I believe that we have to stick to the etymology of communicate, whereby Latin communicare means to 'make shared', and we should take this to mean first and foremost 'making my intentionality and speaker meaning known by/to you'. Of course, it is tempting to integrate Luhmann as he offers a cybernetic systems theory of society for free. However, the focus 
being on Wittgenstein-like language games, we ought to have the individual communicator in focus. Society and its institutions are created by the interactions of the individuals, rather than the individuals being instrumental within intra-societal communication $[17,26,47,48]$. Language itself is one-the basic one-of those institutions, and it is well-known in linguistics that a language may be created from scratch, as is the case with Nicaraguan sign language [49]-another indication that the (wannabe) communicators are linguistic agents and not instruments of communication, quite simply because there was no deaf sign language communication (based on linguistic conventions) before in Nicaragua.

The individual communicators are accordingly the basic level, whereas a Luhmann model would have the linguistic intercourses of the speech community as the monolithic basis, thereby reducing the individual communicators to secondary, instrumental status, as we have already dealt with above. The kind of speech community viable in the individualist model is an extensional set of individuals forming a cohesive communicative network whose ties are the results of communicative contacts, or intercourses. Frequency and depth of contact entrench the network ties. The communicators of a given speech community either actually communicate or are 'on standby'. Potential members of the speech community are pre-linguistic children and members of other speech communities, striving to learn, i.e., develop a competence in the Dialect for themselves.

\section{Cybersemiotics and Total Communication}

We have now paved the way for giving the total picture of communication: we have narrowed down the focus from society to the individual in the previous section. Here, we have to enlarge it from homo loquens to homo communicans.

In Functional Pragmatics [27,50,51] and structural functionalism [16,33], an individual's grammatical competence is conceived of as his/her communicative competence, that is, the individual language user's primarily procedural knowledge (know-how) for producing and comprehending speech in human interaction. What is meant by 'procedural knowledge' (in this paper) is a system of norms, i.e., patterns of behavior. Speaking means following these rules for verbal conduct. In reception, passive knowledge of others' norms is also applied. The model proposed in this paper enlarges the domain of communicative competence to include non-verbal semiotic behavior in addition to verbal behavior, so that communicative competence is competence to perform productive and receptive acts of total communication, verbal as well as non-verbal communicative acts [52].

Total communication is the purview of the total body (its sensory-motor system as transmitter and receiver). The total-communicative display is multimodal, integrating the qualisigns of the different sense modalities. For instance there is a set of biologically hard-wired affects indexically realized as a set of universally recognizable facial visual displays [53] - these symptoms (Bühler's 'expression' above; signs with 'emotive' function in Jakobson's model) are manifestations of the biological system (its interpenetration with the psyche) and play a proto-communicative role in the sign games (Bühler's 'appeal' above; signs with 'conative' function in Jakobson's model). Laughing with joy is a pre-linguistic vocalization which is integrated with the simultaneously encoded and articulated linguistic verbal message, which in the case of vocal (i.e., not sign) verbal language is also a vocalization. In this case the human communicator monitors or controls simultaneously two channels of communication, one at the interpenetration of the psyche with the linguistic system-the language 
games, the other at the interpenetration of the psyche with the biological system-the sign games. It is evident that the two channels are simultaneously controlled, so I shall argue that there must be some kind of psychological 'central processing unit' taking care of this. Notice the important fact that the psychological system controls bodily articulation and perception, i.e., the biological system, which in its turn "controls" the physical system. If we term the communicative capacities of cybernetic signaling and of performing sign games and language games 'pragmatics' - or 'discourse pragmatics', to underline that we communicate in total discourses-the integrated capacity of the central processing unit could be termed InterPragmatics, compare also [54,55]. It is a capacity of the semiotic 'director', the orchestrator of the multimodal semiotic displays.

The psyche of Cybersemiotics forms all sorts of emotions and motivations [57], in addition to (language-based) rationality [58,59]. A primitive form of expression of emotion is by way of pitch, i.e., fundamental frequency of voice, of the emitted signal [60,61]. Language games seem to have developed from sign games (gesture) [62-65], and even words have vestiges of gesture [66]. Some gesturing is inadvertent; some requires visual monitoring [67]. Gesture studies indicate that the level of conventional language games, in addition to verbal language (either vocal or sign), also contains non-verbal 'body language': language-like gestures, pantomime, and so-called emblems (quotables), like the 'okay' sign $[63,64]$. They are conventional but not syntactic and thus only partly comparable to verbal language. (I don't know which consequences, if any, this would have for the model of Cybersemiotics.)

Returning to the concept of a 'central processing unit', there is much evidence that the speaker forms a single idea unit as input to simultaneous, synchronized speaking and gesticulating [14,64]. The single thought, e.g., the conceptualization of a person moving, gets articulated, or embodied, simultaneously by way of symbolic language games (the verbal channel) and iconic sign games (gesticulation). Speech is intentional/volitional, conventional (symbolic), analytic (componentializing, categorical), conceptual, and syntactic, while gesticulation is spontaneous, non-conventional, synthetic (analog), imaginal and global ("prosodic")-the two simultaneous, co-expressive channels are thus complementary, they express the same thought in tandem from two diametrically different, though complementary angles, i.e., in terms of concept and imagery. The display is an integrated multi-modal materialization of a thinking-for/while-communicating verbally and gesturally $[13,14,68]$. The language game level involves a code, or functional discourse grammar [38], a fact that does not in the same degree pertain to the sign game level, where more often than not there is a direct, non-mediated link between the message and the signal articulation (a view to be slightly modified below)-note that even though e.g., flirting is a universal human phenomenon, there are cultural differences and norms (which may cause intercultural misunderstandings and conflict). This explains why I have chosen the term InterPragmatics (not InterGrammar, compare [54]) for the integration of the verbal and gestural levels. The Functional Discourse Grammar model, shown in Figure 10 [38], could be minimally amended so as to allow for gesticulation. 
Figure 10. The Functional Discourse Grammar model of the grammatical component as part of a wider theory of verbal interaction [38].

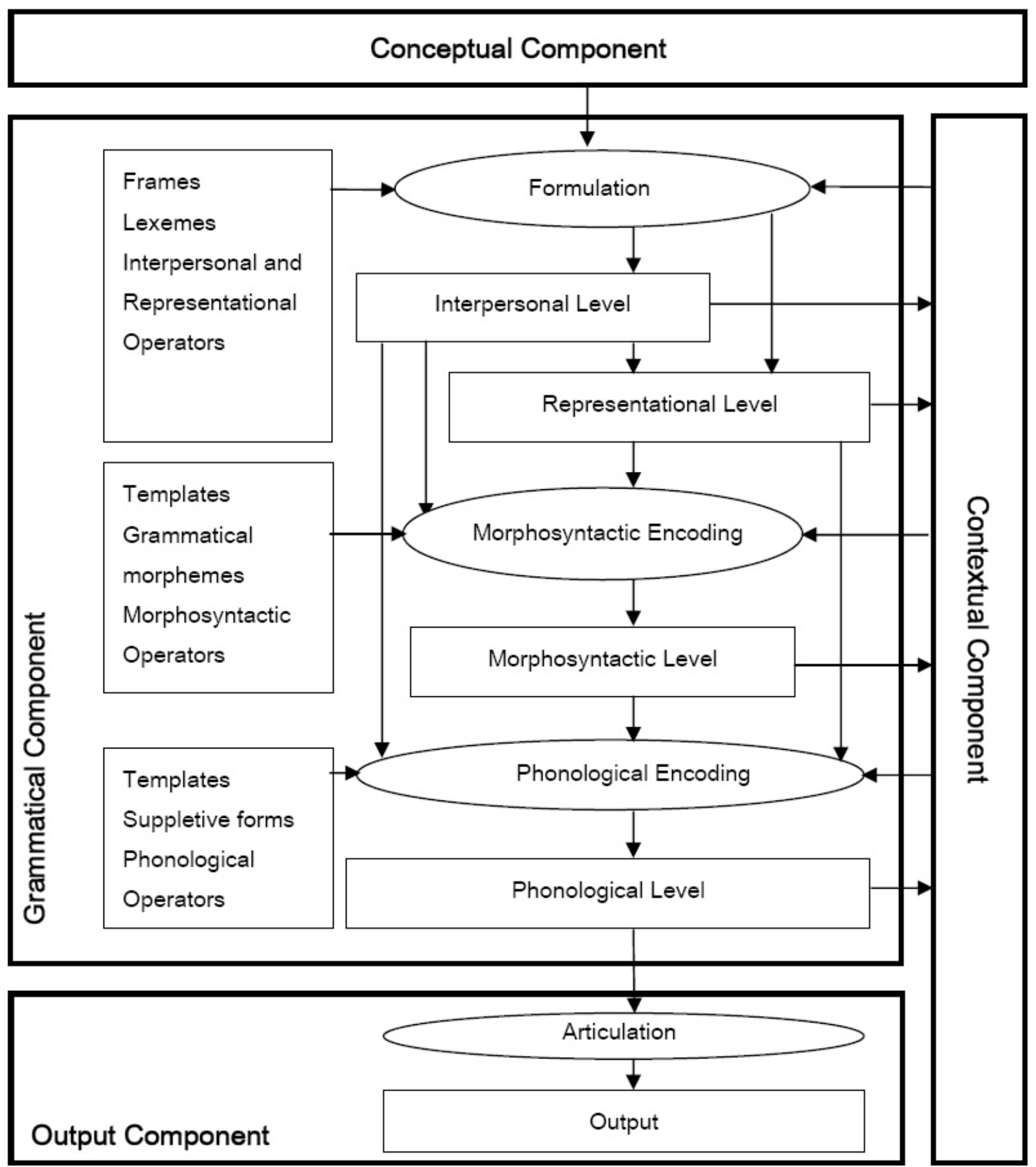

One only has to allow for an arrow pointing from the conceptual component, but skipping the grammar and connecting the former with a parallel (simultaneous) output component which is mainly visual rather than acoustic (there is also non-verbal prosody which would have to be integrated with verbal prosody, cf. above). A comparable computational model is given in [69], repeated here as Figure 11. 
The communicative intention is formed in the Communication Planner (cf. the Conceptual Component in Figure 10 [38]) and is differentiated into an imagery part (in the Image Generator) and a propositional part (in the Message Generator) which are both input to a working memory (the Blackboard interface with mediating multimodal concepts from long term memory). Thereafter the Formulators take over formulating gesture and speech, respectively. The Articulatory Component in Figure 10 corresponds to the Phonation component in Figure 11, whereas the Motor Control component in Figure 11 articulates gesture.

Figure 11. A model of multimodal communication from multimodal thinking [69].

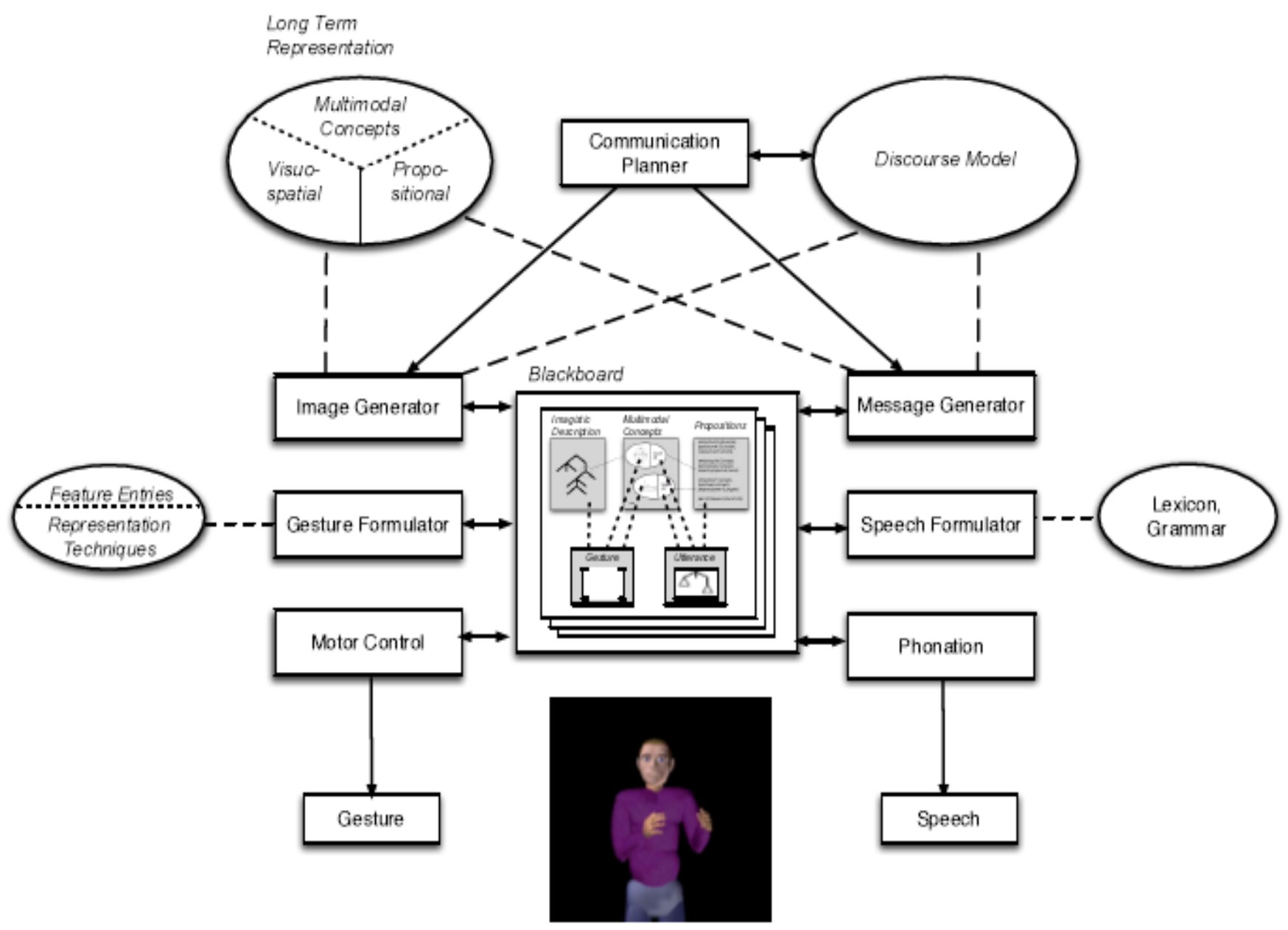

Notice that according to [69], there is a 'morphological' component on the gesture side, which corresponds to the Lexicon/Grammar component on the verbal language side. (A non-modular model is proposed in [70].) Notice that this rough production model has to be supplemented with a reception-comprehension model. Even though there are two channels, they are integrated to such a degree that the timings of the articulations are totally synchronized-the result is 'co-articulation'. For instance, one may observe nodding gestures falling exactly on the accent positions in the verbal-prosodic channel. Here nodding functions as stressing or underlining the same contents that are stressed verbally-prosodically.

The last point I want to adduce to complete the picture of total communication is that over and above the level of language games we have a level of multimediality-verbal language (and gesture) 
may be integrated with other semiotic media to give another sort of co-expression of meaning than the one seen in channel multimodality. The other media are developed after verbal language; they are 'post-linguistic'. When looking back at the Cybersemiotic star (cf. Figure 1), with its leg of language and culture as well as its leg of physical nature, we must mention that communication takes place via a channel (physical nature), but often also involves technologically constructed, artificial media (culture). The first known conventional medium was, of course, writing, i.e., the graphical representation of speech, which evolutionarily derived from picture making. The natural medium of verbal language is obviously the oral and personal one, but the evolution of other media feeds back into the structure of language in the form of media-determined variation, to the effect that we have written style, sms-style, etc. Original, base-line interpersonal, face-to-face communication, naturally, uses just one medium, the oral and personal one, but more often than not communication is, in addition to being multimodal (involving several channels), also multi-medial (e.g., integrating picture communication). The terminal of the receiver may be generalized, as in mass-medial communication $[40,41]$. Such a simple discourse type as televised weather forecasts exemplifies my point: the weather forecaster uses verbal communication integrated with non-verbal gesturing, as well as integrating the use of pictures, satellite films, and temperature tables (including writing, of course). But even ancient Greek theatrical performances are examples of multi-modal, multi-medial (e.g., masks, singing), and mass-medial communication (huge audiences), as are rhapsodic recitals (e.g., Homeric Iliad and Odyssey) where the performer has memorized his text and thereby is able to freely reproduce it at several successive occasions for different audiences.

Figure 12. Communicating bodies: Jealousy and flirtation, by Haynes King (1831-1904).

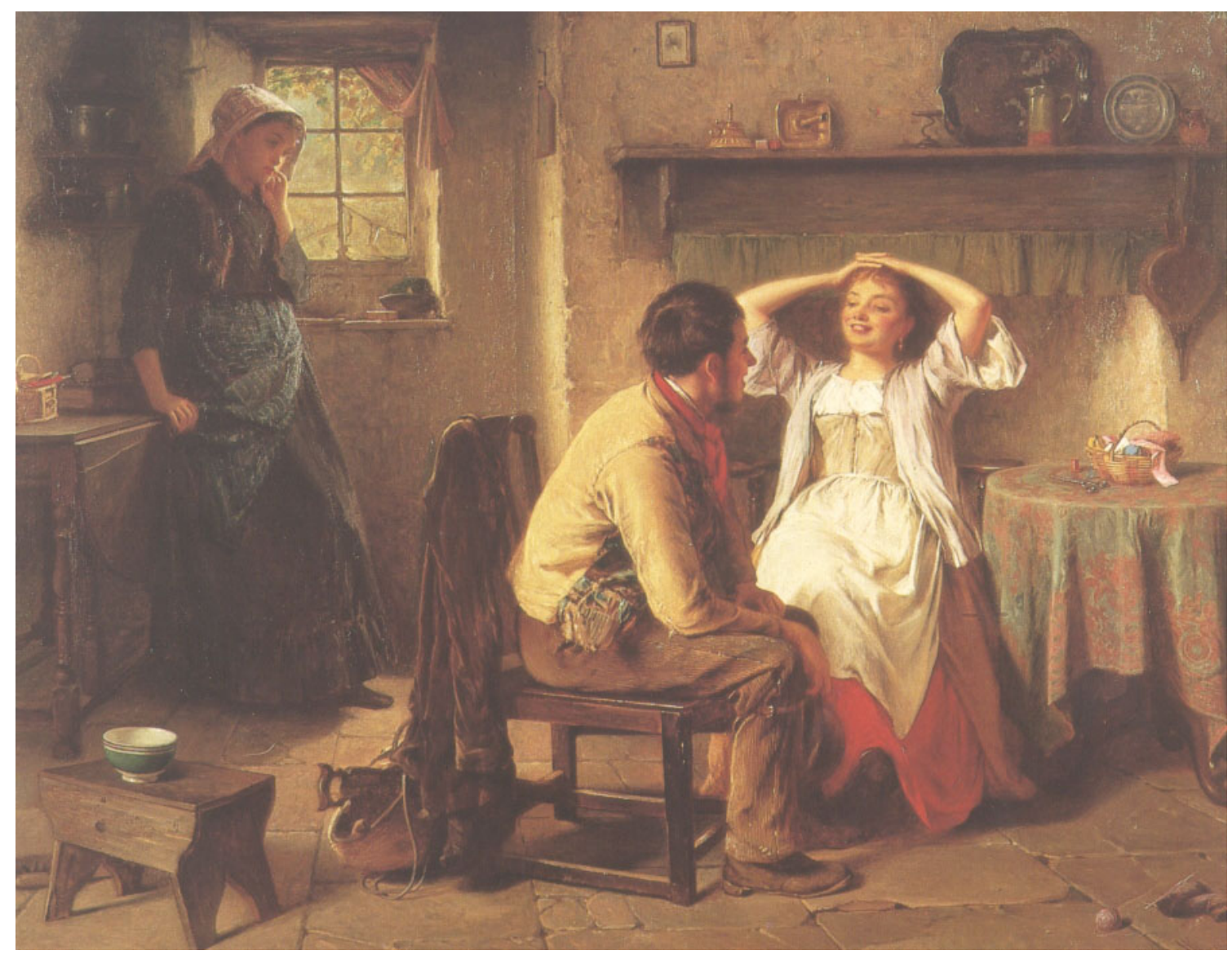




\section{Conclusions}

In the foregoing pages, I have tried to sketch a Cybersemiotic conception of linguistics, understood as a multi-modal and 'medial' discipline integrating theories of verbal and non-verbal as well as mass-medial and multimedial communication into a macro-theory of total communication. This warrants the main title 'from talking heads to communicating bodies', for total communication is performed by whole bodies (persons), not only their (rational) heads-and these communicating persons may adduce also artificial instruments of communication, as well as operate in various sorts of communicative institutions (e.g., mass-media involving distantiated communication and generalized audiences). A linguistic theory should surely be adequate in all four dimensions of the Cybersemiotic star-thus also on the cultural dimension. A comprehensive picture of total communication would be one that simultaneously focuses on physical (e.g., acoustic phonetics), biological (e.g., neurolinguistics, articulatory and auditory phonetics, biolinguistics), psychological (e.g., psycholinguistics, cognitive linguistics), and socio-cultural adequacy (e.g., sociolinguistics, pragmatics). Only this way may we venture calling linguistics a proper part of Peircean semiotics [71].

\section{Acknowledgements}

I want to express my gratitude to Søren Brier (CBS) for many valuable discussions over the last year, without which this paper would not have come into being. Of late, I have got much invaluable inspiration from one of the pioneers of introducing Peircean semiotics into linguistics, Henning Andersen (UCLA), for which I thank warmly. Also many thanks to the three anonymous reviewers for their valuable constructive criticisms, which I have tried to incorporate as far as possible.

\section{References}

1. Brier, S. Cybersemiotics: Why information is not Enough; University of Toronto Press: Toronto, Canada, 2008.

2. Brier, S. The necessity of trans-scientific frameworks for doing interdisciplinary research: Developed from a conference paper for Paradigms lost and paradigms gained: Negotiating interdisciplinarity in the twenty-first century, Calgary, May 2001. Kybernetes. 2006, 35, 403-425; Available on-line: http://www.emeraldinsight.com/Insight/ViewContentServlet? (accessed March 2, 2010).

3. Brier, S. Luhmann semiotized. J. Sociocyb. 2002/2003, 3, 13-23; Available on-line: http://www.unizar.es/sociocybernetics/Journal/JoS3-2.pdf (accessed March 2, 2010).

4. Brier, S. Luhmann og den manglende korporligt situerede. In Luhmann og erkendelseEpistemologi, anvendelse og nyorientering; Tække, J., Ed.; Forlaget Unge Pædagoger: København, Danmark, 2006; pp. 215-246.

5. Brier, S. The paradigm of Peircean biosemiotics. Signs 2008, 2, 30-81; Available on-line: http://vip.db.dk/signs/artikler/Brier\%20(2008)\%20the\%20paradigm\%20of\%20peircean\%20biose miotics.pdf (accessed March 2, 2010). 
6. Brier, S. Information seen as part of the development of living intelligence: The five-leveled Cybersemiotic framework for FIS. Entropy 2003, 5, 88-99; Availabel on-line: http://www.mdpi.org/entropy/papers/e5020088.pdf (accessed March 2, 2010).

7. Brier, S. Levels of Cybersemiotics: Possible ontologies of signification. Cogn. Sem. 2009, 4, 28-62.

8. Brier, S. Cybersemiotic Pragmaticism and Constructivism. Const. Found. 2009, 5, 19-39; Available on-line: http://www.univie.ac.at/constructivism/journal/articles/5/1/019.brier.pdf (accessed March 2, 2010).

9. Brier, S. The Cybersemiotic model of communication: An evolutionary view on the threshold between semiosis and informational exchange. TripleC 2003, 1, 71-94; Available on-line: http://triple-c.at/index.php/tripleC/article/view/6/4 (accessed March 2, 2010).

10. Maturana, H.R. Ontology of observing. The biological foundations of self consciousness and the physical domain of existence; Conference Workbook: Texts in Cybernetics, American Society for Cybernetics Conference, Felton, CA, USA, 18th-23th October, 1988. Ed. Instituto de Terapia Cognitiva de Santiago de Chile (INTECO): Santiago de Chile, Chile; Available on-line: http://www.inteco.cl/biology/ontology/ (accessed March 2, 2010).

11. Luhmann, N. Social Systems; Stanford University Press: Stanford, CA, USA, 1995.

12. Dik, S.C. The Theory of Functional Grammar; Hengeveld, K., Ed.; Mouton de Gruyter: Berlin, Germany, 1997; Volume 2.

13. Slobin, D.I. Thinking for speaking. In Proceedings of the Thirteenth Annual Meeting of the Berkeley Linguistic Society; Aske, J., Beery, N., Michaelis, L., Filip, H., Eds.; Berkeley Linguistic Society: Berkeley, CA, USA, 1987; pp. 435-445.

14. McNeill, D.; Duncan, S.D. Growth points in thinking for speaking. In Language and Gesture; McNeill, D., Ed.; Cambridge University Press: Cambridge, UK, 2000; pp. 141-161.

15. Brier, S. Copenhagen Business School, Copenhagen, Denmark, Personal communication.

16. Coseriu, E. Linguistic competence: What is it really? Mod. Lang. Rev. 1985, 80.4, XXV-XXXV.

17. Thomsen, O.N. Towards an integrated functional-pragmatic theory of language and language change. In commemoration of Eugenio Coseriu (1921-2002)”. In Competing Models of Linguistic Change. Evolution and beyond; Thomsen, O.N. Ed.; Benjamins: Amsterdam, The Netherlands \& Philadelphia, PA, USA, 2006; pp. 307-337.

18. Brier, S. Applying Luhmann's systems theory as part of a transdisciplinary frame for communication science. Cybern. \& Hum. Know. (C\&HK) 2007, 14. 29-65; Available on-line: http://www.imprint.co.uk/C\&HK/ (accessed March 2, 2010).

19. Searle, J.R. Collective intentions and actions. In Intentions in Communications; Cohen, P., Morgan, J., Pollack, M.E., Eds.; MIT Press, Bradford Books: Cambridge, MA, USA, 1990; pp. 401-416.

20. Brier, S. Ecosemiotics and Cybersemiotics. Sign Syst. Stud. 2001, 29.1, 107-120.

21. Lyon, P. Autopoiesis and knowing: Reflections on Maturana's biogenic explanation of cognition. Cybern. \& Hum. Know. (C\&HK) 2004, 11.4, 21-46; Availabel on-line: http://www.imprint.co.uk/C\&HK/ (accessed March 2, 2010). 
22. Russell, D.; Ison, R. Maturana's intellectual contribution: A coreography of conversation and action. Cybern. \& Hum. Know. (C\&HK) 2004, 11.2, 36-48; Availabel on-line: http://www.imprint.co.uk/C\&HK/ (accessed March 2, 2010).

23. Imoto, S. The philosophical nature of Maturana's theory of perception. Cybern. \& Hum. Know. (C\&HK) 2004, 11.2, 12-20; Availabel on-line: http://www.imprint.co.uk/C\&HK/ (accessed March 2, 2010).

24. Imoto, S. Nothing as Plenum: Lao-tzu's Way and Maturana’s Substratum. Cybern. \& Hum. Know. (C\&HK) 2005, 12.4, 107-114; Availabel on-line: http://www.imprint.co.uk/C\&HK/ (accessed March 2, 2010).

25. Andersen, H. Abductive and deductive change. Lang. 1973, 49, 567-595.

26. Searle, J.R. The Construction of Social Reality; The Free Press: New York, NY, USA, 1995.

27. Thomsen, O.N. Funktionel Diskurs Grammatik-og Funktionel Pragmatik. Nydanske Sprogstudier (NyS) 2008, 36, 63-119.

28. Chomsky, N. [interviewee, 1972] Noam Chomsky. In Discussing language. Dialogues with Wallace L. Chafe, Noam Chomsky, Algirads J. Greimas, M.A.K. Halliday, Peter Hartmann, George Lakoff, Sydney M. Lamb, André Martinet, James McCawley, Sebastian K. Šaumjan, and Jacques Bouveresse; Parret, H. Ed. Mouton: The Hague, The Netherlands \& Paris, France, 1974; pp. 27-54.

29. Chomsky, N. New Horizons in the Study of Language and Mind; Cambridge University Press: Cambridge, UK, 2000.

30. Aranguren, J.L.L. Human Communication; McGraw-Hill: New York, NY, USA, 1967.

31. de Saussure, F. Course in General Linguistics; Bally, C., Sechehaye, A., Eds.; Trans. Roy Harris. Open Court: La Salle, IL, USA, 1983

32. Bühler, K. Sprachteorie; Fischer: Jena, Germany, 1934.

33. Andersen, H. Language structure and semiotic processes [1975]. Arbejdspap. Inst. Ling. Kbh. Univ. (APILKU) 1984, 3, 33-54.

34. Durst-Andersen, P. The grammar of linguistic semiotics-reading Peirce in a modern linguistic light. Cybern. \& Hum. Know. (C\&HK) 2009, 16, 37-79; Availabel on-line: http://www.imprint.co.uk/C\&HK/ (accessed March 2, 2010).

35. Boye, K. Kommunikation à la Luhmann. Synsvinkler 1998, 21, 21-40.

36. Jakobson, R. Closing statements: Linguistics and poetics. In Style in language; Sebeok, T.A., Ed.; The MIT Press: Cambridge, MA, USA, 1960; pp. 350-377.

37. Malinowski, $\mathrm{B}$. The problem of meaning in primitive language. Concluding essay in The meaning of meaning; Ogden, C.K.; Richards, I.A., Eds., Routledge: London, UK, 1923; pp. 296-336.

38. Hengeveld, K.; Mackenzie, J.L. Functional Discourse Grammar: A Typologically-Based Theory of Language Structure; Oxford University Press: Oxford, UK, 2008.

39. Shannon, C.E. A mathematical theory of communication. Bell Syst. Tech. J. 1948, 27, 379-423; 623-656; Availabel on-line: http://plan9.bell-labs.com/cm/ms/what/shannonday/shannon1948.pdf (accessed March 2, 2010)

40. Laermans, R. Mass media in contemporary society: A critical appraisal of Niklas Luhmann's systems view. Cybern. \& Hum. Know. (C\&HK) 2005, 12.4, 51-70; Availabel on-line: http://www.imprint.co.uk/C\&HK/ (accessed March 2, 2010). 
41. Misheva, V. Luhmann's Systems Theory and the question of the mass media. Cybern. \& Hum. Know. (C\&HK) 2005, 12.4, 23-50; Availabel on-line: http://www.imprint.co.uk/C\&HK/ (accessed March 2, 2010).

42. Foulger, D. An ecological model of the communication process. Unpublished 2004; Availabel online: http://davis.foulger.info/papers/ecologicalModelOfCommunication.htm (accessed March 2, 2010).

43. Tomasello, M.; Carpenter, M.; Call, J.; Behne, T.; Moll, H. Understanding and sharing intentions: The origins of cultural cognition. Behav. Brain Sci. (BBS) 2005, 28, 675-735; Availabel on-line: http://journals.cambridge.org/action/displayFulltext?type=1\&pdftype=1\&fid=346982\&jid=BBS\& volumeId=28\&issueId=05\&aid=346981 (accessed March 2, 2010).

44. Hawkins, J.A. Efficiency and Complexity in Grammars; Oxford University Press: Oxford, UK, 2004.

45. Ross, A. Directives and Norms; Routledge and Kegan Paul: London, UK, 1968.

46. Ross, A. Skyld, ansvar og straf; Berlingske Forlag: København, Denmark 1970.

47. Searle, J.R. Mind, Language and Society. Philosophy in the Real World; Basic Books: New York, NY, USA, 1998.

48. Searle, J.R. Freedom and Neurobiology. Reflections on Free Will, Language, and Political Power; Columbia University Press: New York, NY, USA, 2007.

49. Tomasello, M. Constructing A Language: A Usage-Based Theory of Language Acquisition; Harvard University Press: Harvard, MA, USA, 2005.

50. Thomsen, O.N. Nyt fra Funktionel Pragmatik-fronten-FP som den sproglige komponent i en kybernetisk semiotik. In Sprogvidenskab i glimt. 70 tekster om sprog i teori og praksis [Univ. South. Den. Stud. Ling. 18.]; Farø, K., Holsting, A., Larsen, N.-E., Mogensen, J.E., Vinther, T., Eds.; Syddansk Universitetsforlag: Odense, Denmark, 2009; pp. 471-478.

51. Thomsen, O.N. Back to basics: Funktionel Pragmatik-Mod en retorisk-semiotisk kommunikationsteori om sprog og tale. In Dramatikken i Grammatikken; Therkelsen, R., Jensen, E.S., Eds.; Department of Culture and Identity, Roskilde University: Roskilde, Denmark, 2009; pp. 423-438.

52. von der Lieth, L.; Kuschel, R.; Petersen, A.F. Kommunikationens veje. Om basale kommunikationsformer hos mennesker og dyr; Nyt Nordisk Forlag Arnold Busck: København, Denmark, 1993.

53. Stenner, P. An outline of an autopoietic systems approach to emotion. Cybern. \& Hum. Know. (C\&HK) 2005, 12.4, 8-22; Availabel on-line: http://d.wanfangdata.com.cn/NSTLQK_NSTL_ QK10810348.aspx (accessed March 2, 2010).

54. Arndt, H.; Janney, R.W. InterGrammar. Toward an Integrative Model of Verbal, Prosodic, and Kinesic Choices in Speech; Mouton de Gruyter: Berlin, Germany \& New York, NY, USA, 1987.

55. Arndt, H.; Janney, R.W. Verbal, prosodic, and kinesic emotive contrasts in speech. J. Pragm. (JoP) 1991, 15, 521-549.

56. Caffi, C.; Janney, R.W. Toward a pragmatics of emotive communication. J. Pragmatics (JoP) 1994, 22, 325-373.

57. Katzenelson, B. Drivkræfter, følelser og erkendelse; Hans Reitzels Forlag: København, Denmark, 2004. 
58. Searle, J.R. Rationality in action; The MIT Press: Cambridge, MA, USA, 2001.

59. Searle, J.R. Consciousness and Language; Cambridge University Press: Cambridge, UK, 2002.

60. Ohala, J.J. An ethological perspective on common cross-language utilization of F0 of voice. Phonetica 1984, 41, 1-16.

61. Ohala, J.J. Ethological theory and the expression of emotion in the voice. In ICSLP 96. Proceedings of the 4th International Conference on Spoken Language Processing, Philadelphia, PA, USA, October 3rd-6th, 1996; University of Delaware: Wilmington, DC, USA; Volume 3; pp. 1812-1815.

62. Kendon, A. Signs for Language Origins? Publ. J. Semiot. (PJOS) 2008, 2.2, 2-29; Availabel online: http://www.semiotics.ca/issues/pjos-2-2.pdf (accessed March 2, 2010).

63. Kendon, A. Gesture: Visible Action as Utterance; Cambridge University Press: Cambridge, UK, 2004.

64. McNeil, D. Gesture and Thought; University of Chicago Press: Chicago, IL, USA, 2005.

65. Zlatev, J. From proto-mimesis to language: evidence from primatology and social neuroscience. J. Physiol.-Paris 2008, 102, 137-151; Available on-line: http://www.sciencedirect.com/ science?_ob=ArticleURL\&_udi=B6VMC-4SM0XFP-1\&_user=634332\&_coverDate=05\%2F31 \%2F2008\&_alid=1229193889\&_rdoc=1\&_fmt=high\&_orig=search\&_cdi=6147\&_sort=r\&_doca nchor $=\&$ view $=$ c\&_ct $=1 \&$ \&acct $=$ C000033618\&_version $=1 \&$ \&urlVersion $=0 \&$ \&userid $=634332 \& m$ d5=c2120c18db860397fb65e2cfcdf0c80c (accessed March 2, 2010).

66. Janney, R.W. Words as gestures. J. Pragmatics (JoP) 1999, 31, 953-972.

67. McNeill, D.; Quaeghebeur, L.; Duncan, S.D. IW-“the man who lost his body”. In Handbook of Phenomenology and Cognitive Science; Schmicking, D., Gallagher, S., Eds.; Springer: Berlin, Germany, 2009.

68. Slobin, D.I. Language and thought online: Cognitive consequences of linguistic relativity. In Language in Mind: Advances in the Study of Language and Thought; Gentner, D., GoldinMeadow, S., Eds.; The MIT Press: Cambridge, MA, USA, 2003; pp. 157-192.

69. Sowa, T.; Kopp, S.; Duncan, S.D.; McNeill, D.; Wachsmuth, I. Implementing a non-modular theory of language production in an embodied conversational agent. In Embodied Communication; Wachsmuth, I., Lenzen, M., Knoblich, G., Eds.; Oxford University Press: Oxford, UK, 2009; Chapter 18.

70. Kopp, S.; Bergmann, K; Wachsmuth, I. Multimodal communication from multimodal thinkingtowards an integrated model of speech and gesture production. Intern. J. Sem. Comp. (IJSC) 2008, 2, 115-136.

71. Peirce, C.S. Chance, Love, and Logic. Philosophical Essays; Ketner, K.L., Ed.; University of Nebraska Press: Lincoln, NE, USA, 1998.

(C) 2010 by the authors; licensee Molecular Diversity Preservation International, Basel, Switzerland. This article is an open-access article distributed under the terms and conditions of the Creative Commons Attribution license (http://creativecommons.org/licenses/by/3.0/). 